\title{
Geohydrology of the
}

Souris River Valley in

the Vicinity of Minot,

North Dakota

GEOLOGICAL SURVEY WATER-SUPPLY PAPER 1844

Prepared in cooperation with the North Dakota State Water Commission. and the city of Minot, North Dakota 


\section{Geohydrology of the}

Souris River Valley in

the Vicinity of Minot,

North Dakota

By WAYNE A. PETTYJOHN

GEOLOGICAL SURVEY WATER-SUPPLY PAPER 1844

Prepared in cooperation with the

North Dakota State Water Commission.

and the city of Minot, North Dakota

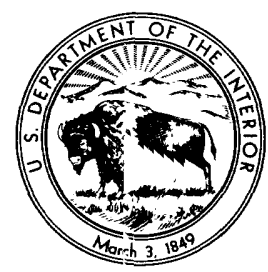




\section{UNITED STATES DEPARTMENT OF THE INTERIOR}

STEWART L. UDALL, Secretary

\section{GEOLOGICAL SURVEY}

William T. Pecora, Director

Library of Congress eatalog-card No. GS 6ī-192 


\section{CONTENTS}

Abstract. Page

Introduction $\ldots \ldots \ldots \ldots$

Purpose and scope of the investigation

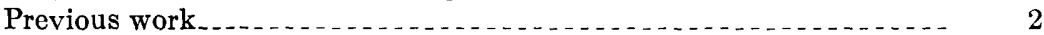

Acknowledgments _._.

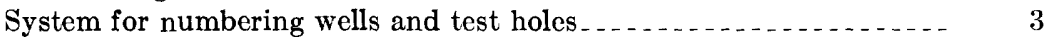

Methods of investigation . . . . . . . . . . . . . . . . . . . . . . . 4

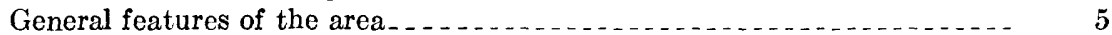

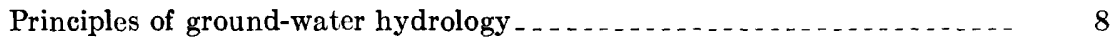

Tertiary deposits and their water-bearing properties $\ldots \ldots \ldots 11$

Quaternary deposits and their water-bearing properties........... 13

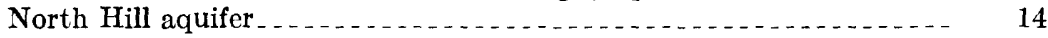

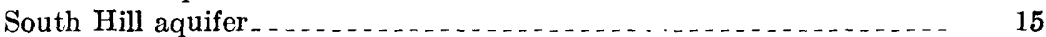

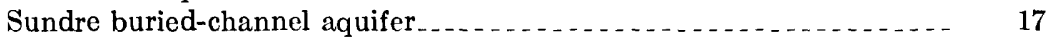

Lower Souris aquifer._._._._.

Northwest buried-channel aquifer _. . . . . . $2 \ldots$

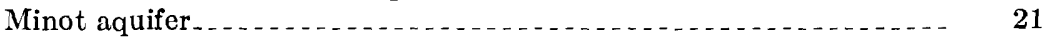

Ground-water movement.

Fluctuations of water levels................... 23

Artesian and water-table conditions.................... 24

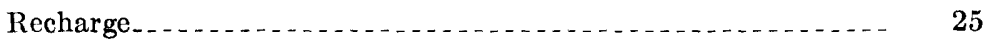

Natural recharge _.................................. 25

Feasibility of artificial recharge 33

Discharge._._.

Evapotranspiration, scepage to streams, and underflow _... 36

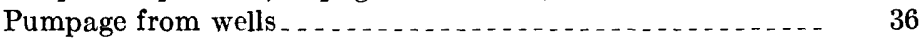

Aquifer hydraulics $\ldots \ldots \ldots$

Cocfficients of permeability, transmissibility, and storage,

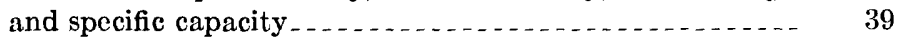

Interference and drawdown. ......................... 43

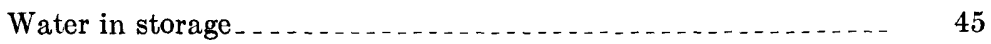

Quality of water. 47

Summary and conclusions _.............. 51

Selected references_._. 


\section{JLLUSTRATIONS}

Plate 1. Surficial geologic map of Souris River valley, Minot area,

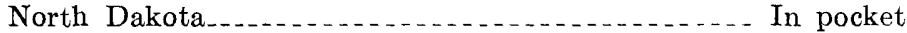

2. Map showing location and hydrology of the North Hill, South Hill, lower Souris, Sundre buried-channel, and nor ${ }^{+}$hwest buried-channel aquifers, Souris River valley, Minot area, North Dakota In pocket

3. Maps showing lithofacies grain-size ratio, generalized piezometric surface, and decline of water level for the Minot aquifer, Souris River valley, Minot area, North Dakota. In pocket

FIGURE 1. Diagram showing system of numbering wells and test holes...

2. Map showing physiographic provinces in North Dakota and

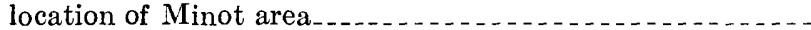

3. Graphs showing annual and monthly mean discharge of the Souris River

4. Graph showing particle-size distribution of selected samples from the Minot aquifer at Oak Park in Minot. ..........

5. Graph showing relation between precipitation, Souris River discharge, and water level in the central part of the Minot aquifer

6. Hydrographs showing water-level fluctuation of Minot municipal wells

7. Map showing areas of artesian and water-table conditions in the Minot aquifer, 1964

8. Map showing areas of recharge to the Minot aquifer.......-

9. Map showing location of potential artificial-recharge sites in western Minot.......................................

10. Graph showing annual pumpage of Minot municipal wells, 1944-63.

11. Graph showing monthly pumpage from Minot municipal wells and from the Souris River, February 1963-August 19 $\{4$. -

12. Map showing distribution and magnitude of pumpage from 14 wells in 1963

13. Graph showing predicted drawdowns near city wells $5 \mathrm{cnd} 7$, each discharging $700 \mathrm{gpm}$ for selected periods...........

14. Graph showing predicted drawdowns near city wells 8 and 15 , each discharging $700 \mathrm{gpm}$ for selected periods

15. Graph showing relation of dissolved-solids content to specific conductance in ground water in the vicinity of Minot.-

16. Map showing chemical quality of water and dissolved solids

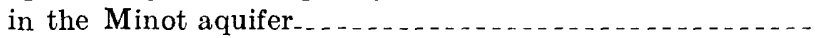

\section{TABLES}

TABLE 1. Physical and hydrologic properties of samples from the Minot aquifer

2. Transmissibility of the Minot aquifer

3. Coefficient of storage for the Minot aquifer at selected sites

4. Specific capacities of selected wells near Minot.........

5. Chemical analyses of water from the Minot aquifer........ 


\title{
GEOHYDROLOGY OF THE SOURIS RIVER VALLEY IN THE VIGINITY OF MINOT, NORTH DAKOTA
}

\author{
By Wayne A. Pettyjohn
}

\begin{abstract}
ABSTRRACT
The Minot area is in the north-central part of North Dakota and includes part of the Souris River valley. The region is covered by glacial drift of late Wisconsin age except in small areas where the Fort Union Formation of Tertiary age crops out. Thickness of the drift is controlled by the topography of the bedrock. In places the drift is more than $\mathbf{4 5 0}$ feet thick, but it averages atout 100 feet thick.
\end{abstract}

Water from the Fort Union Formation is soft and is of sodium bicarbonate type that is undesirable for many uses. Wells in the formation produce only a few gallons per minute.

Six glacial aquifers were studied in the report area, but detailed work was limited to the Minot aquifer. The Sundre buried-channel and the lower Souris aquifers contain large quantities of hard water of good chemical quality, but little is known of their hydraulic characteristics owing to lack of development. The North Hill and South Hill aquifers generally provide small quantities of hard water that may be high in iron and sodium. The northwest buried-rhannel aquifer has a high content of iron and chloride. Locally as much as 1,000 gallons per minute may be pumped from it.

The Minot aquifer is a thick deposit of sand and gravel confined to the Souris River valley. The water level has declined more than 70 feet since the first municipal well began pumping in 1916. In some places the water level in the aquifer declined more than 20 feet during 1961-1963. The rapid decline in water level indicates that a serious water shortage may arise in the near future unless counter measures are taken to prevent it.

The Minot aquifer is under both artesian and water-table conditicns. In places the transmissibility exceeds 250,000 gallons per day per foot. In 1963,13 municipal wells pumped an average of nearly 4 million gallons per day from the aquifer. Some wells produce as much as 1,000 gallons per minute.

The Minot aquifer receives most of its recharge from the buried glaciofiuvial deposits and from the Souris River. Natural recharge probably average: about 3 million gallons per day. About 56,000 acre-feet of water available to wells was in storage in 1963.

Artificial recharge could be used to counteract the rapid decline ir water levels. Several feasible artificial recharge sites are in the western part of Minot, where highly permeable sand and gravel crop out. 


\section{INTRODUCTION}

In Octaber 1963, officials of the city of Minot, N. Dak., requested that the U.S. Geological Survey, in cooperation with the North Dakota State Water Commisison, conduct a ground-water investigation in and near the city. A preliminary study of existing ground-water records of the Minot area indicated that the water level in the Minot aquifer had declined more than 70 feet in the central part of the city since pumping began in 1916. Such declines suggest a serious reduction in the amount of water stored in the aquifer. Also, earlier theories that the sand and gravel which form the Minot aquifer extend the entire length of the Souris River valley were proved untenable by recent test drilling. Accordingly, a need arose to restudy the municipal water-supply problems in the vicinity of Minot.

\section{PURPOSE AND SCOPE OF THE INVESTIGATION}

The purpose of this investigation was fourfold : to collect and analyze samples from, and information on, all wells of moderate to large discharge in the Minot area; to learn the extent of the Minot aquifer by means of test drilling; to determine if other ground-water supplies are available; and to determine which areas could feasibly be developed as artificial-recharge sites.

\section{PREVIOUS WORK}

The earliest data on the Minot aquifer were reported by Simpson (1929) in his study of the ground-water resources of the State. Andrews (1939) reported on the geology and coal resources of the Minot region, but he did not include ground-water data. Akin (1947) prepared a very comprehensive report on the geologic and hydrologic conditions of the Minot aquifer; his report provided a foundation for this report. Lemke (1960) discussed the geology of the Souris River area and reviewed some of the published data on the Minot. aquifer. Bradley's (1963) report summarized Akin's wcrk and presented some streamflow data.

\section{ACKNOWLEDGMENTS}

The fieldwork on this project was done during November 1963August 1964. Test holes were drilled by the North Drkota State Water Commission by use of a hydraulic rotary-drill rig. The study was done under the direction of D. W. Brown, district geologist, U.S. Geological Survey. Vernon Fahy and Glen Berg, city of Minot employees, greatly facilitated the project by giving willingly of their time and by making available to the author pertinent records on water levels, production, and test holes. 


\section{SYSTEM FOR NUMBERING WELLS AND TEST HOLES}

Figure 1 illustrates the well-numbering system used in this re nort; the system is based on the grid system used by the U.S. Bureau of Land Management. The first number in a well-location number indicates the township north of a base line in Arkansas. The second number denotes the range west of the fifth principal meridan The third number indicates the section in which the well is located. The lowercase letters given after the section number indicate the position of the well

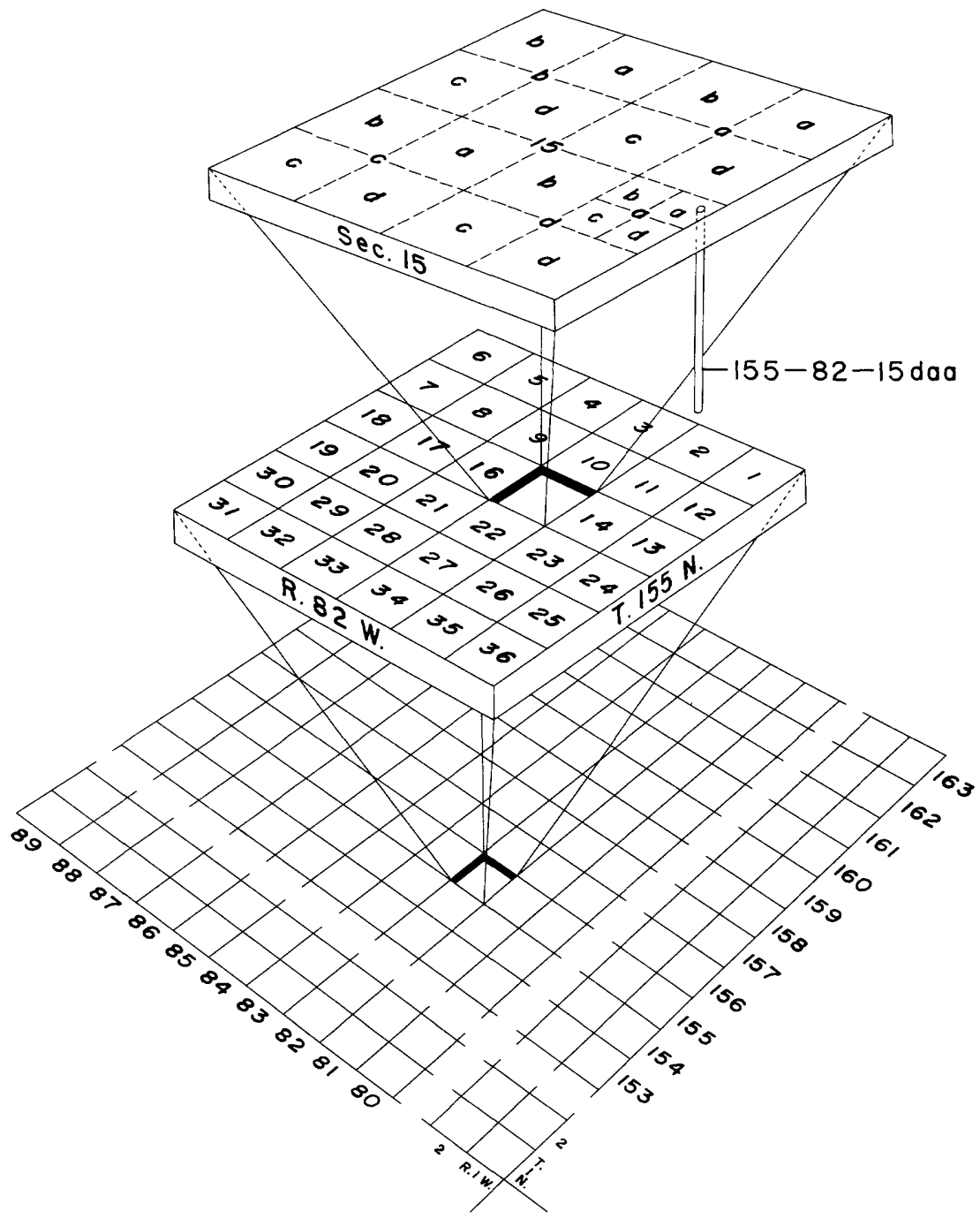

Figure 1.--Syst'em of numbering wells and test holes. 
within the section. The letter " $a$ " refers to the northeast quarter; " $b$," the northwest quarter; "c," the southwest quarter; and "d," the southeast quarter. Succeeding letters refer to the quarter-quarter section and the quarter-quarter-quarter section, or 10-acre tract. Where more than one well is present in a 10 -acre tract, consecutive numbers beginning with 2 are added to the letters in the order in which the wells or test holes are inventoried. For example, the designation 155-82-15aba2 indicates that this is the second well invertoried in the NE $1 / 4 \mathrm{NW} 1 / 4 \mathrm{NE} 1 / 4$ of sec. 15 , T. 155 N., R. 82 W. (fig. 1 ).

\section{METHODS OF INVESTIGATION}

Information for this report was obtained from test drilling and geologic mapping and from well inventories, water-level reasurements, and water-production-data evaluations. Records and logs of wells and test holes, quality-of-water information, and water-level data were presented in a separate report (Pettyjohn and Hills, 1965).

Some evaluations or interpretations presented in this report are necessarily qualified, for many assumptions were required owing to the lack of sufficient available geologic and hydrologic data. Some of the problems encountered in the study are as follows:

1. The production wells of the city of Minot do not penet "ate the entire thickness of the aquifer.

2. Unusally difficult drilling conditions were encountered curing the test drilling of the Minot aquifer; therefore, the test holes did not penetrate the full thickness of the aquifer.

3. All production wells in the area are constructed in such a manner that measurement of water levels in them is difficult or impossible.

4. Available records of pumpage and water levels for the period 1946-63 are either nonexistent or of questionable accuracy.

5. Detailed and accurate data on the production wells are not available.

6. Aquifer characteristics in the central part of Minot were determined in 1946 from results of a single test, and the characteristics of the other parts of the aquifer are inferred.

Although the available geologic data in the area at the time of this study were meager, a series of maps of lithofacies grain sizes were constructed to aid geologic interpretation. This type of map apparently has considerable value in geohydrologic studies, as discussed by Pettyjohn and Randich (1965 a, b). Lithofacies grain-size maps illustrate two geologic characteristics: (1) lithology or rock type, as based on the percentage of sand, gravel, and clay, and (2) the ratio of sand and gravel to clay, as indicated by the grain-size lines. On these maps the lithologic type or lithofacies of an area represents a gross quantitative rock type which may be separated by a line from another rock type of sufficiently distinct characteristics. Lithofacies maps show the 
general distribution of certain rock types such as those types composing the Minot aquifer.

\section{GENERAL FEATURES OF THE AREA}

The Minot area is near the west margin of the Central Lowland physiographic province. Most of the area is in the Souris River valley; however, the area extends from 3 miles west of Minot to 7 miles southeast of Minot along the river and the adjacent uplands (fig. 2). The area contains about 45 square miles. Except for the walls of the Souris River valley, the land is relatively flat and has a local relief of about 100 feet. The maximum relief, including the valley walls, is about 250 feet. The area is drained by the southeastflowing Souris River, which rises in Canada and has a relatively large drainage basin of approximately 11,300 square miles. However, the flow of the river (which is seldom uniform) is controlled almost entirely by regulation of Lake Darling, about $121 / 2$ airline miles upstream from Minot. The Souris River has a gradient of less than 2 feet per mile in its meanders across the 1- to 3-mile-wide flood plain. The channel generally ranges from 8 to 30 feet in width, and the channel banks are only a few feet above the river level. The average annual discharge of the river for the period 1903-63 at the U.S. Geological Survey gaging station above Minot (NW1/4 NW1/4 SE1/4 sec. 17, T. 155 N., R. 83 W.) is 100,600 acre-feet. However, the river may cease to flow in the late spring and the winter (fig. 3), owing to regulation by several dams and to prolonged drought.

The average ammual precipitation in the Minot area in the pariod 1930-63 was 15.90 inches, and that in the State during the same prriod was 16.58 inches (Bavendick, 1952; U.S. Weather Bur., 1960-63). About half the annual precipitation is received during May-July. Most of the rainfall occurs during summer convective thunderstorms, which commonly produce large quantities of water within short periods of time and in small areas. Flash floods are not uncommon, but several dams along the major water courses have considerably reduced the damage potential.

Summer temperatures of $100^{\circ} \mathrm{F}$ or warmer and winter temperatures of $-20^{\circ} \mathrm{F}$ or colder are not uncommon. The average temperature at Minot during the 34 -year period $1930-63$ was $40.3^{\circ} \mathrm{F}$. D uring January the relative humidity ranges from 75 to 80 percent; during July the relative humidity at noon ranges from 45 to 50 percent (Bavendick, 1952, p. 46).

The study area is encompassed by a sparsely populated ranching and farming area. Minot, the largest city, has a population (as of 1964) of about 35,000 , of which about 1,500 are students at I Tinot 
6 GEOHYDROLOGY, SOURIS RIVER VALLEY, MINOT, N. DAK.

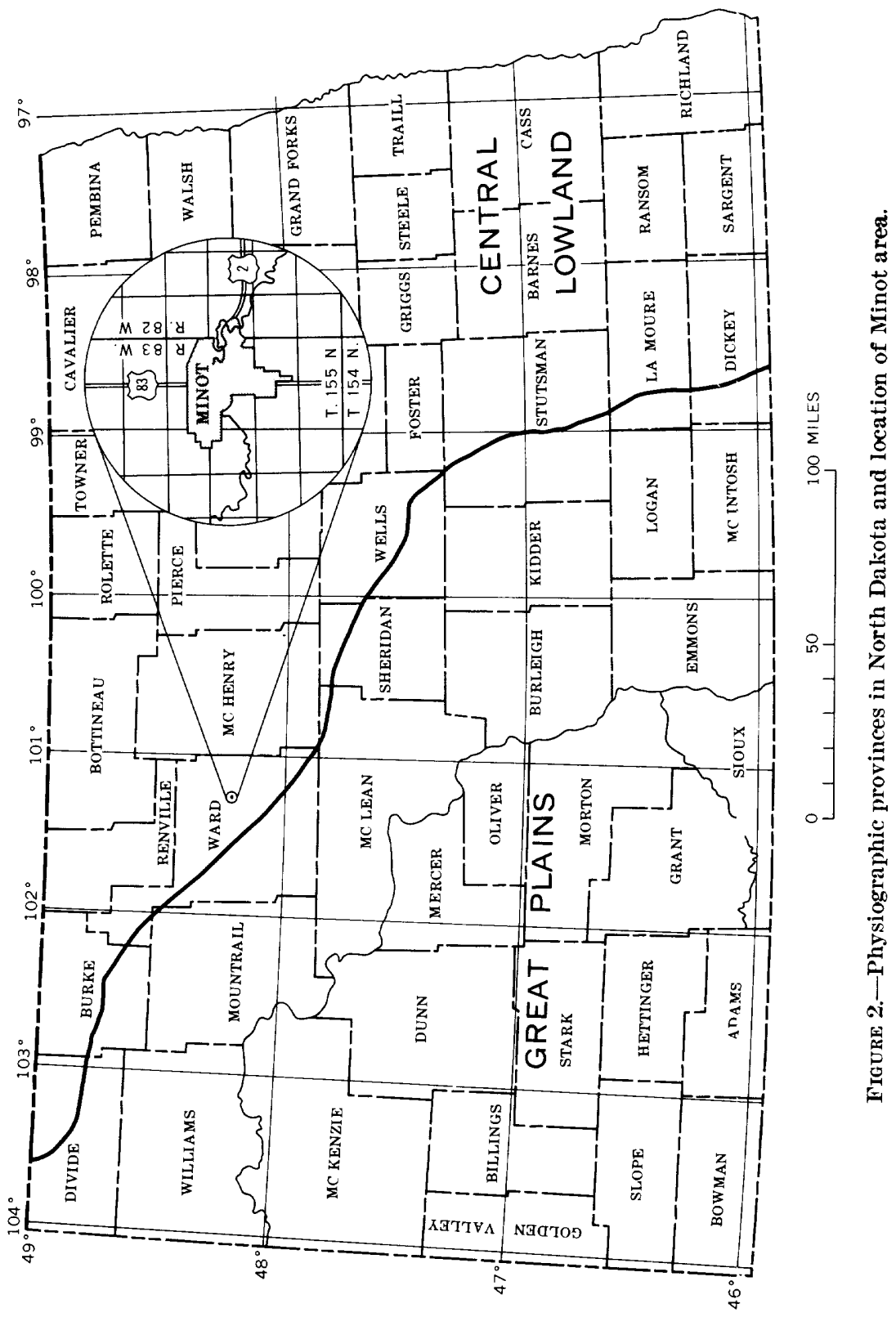



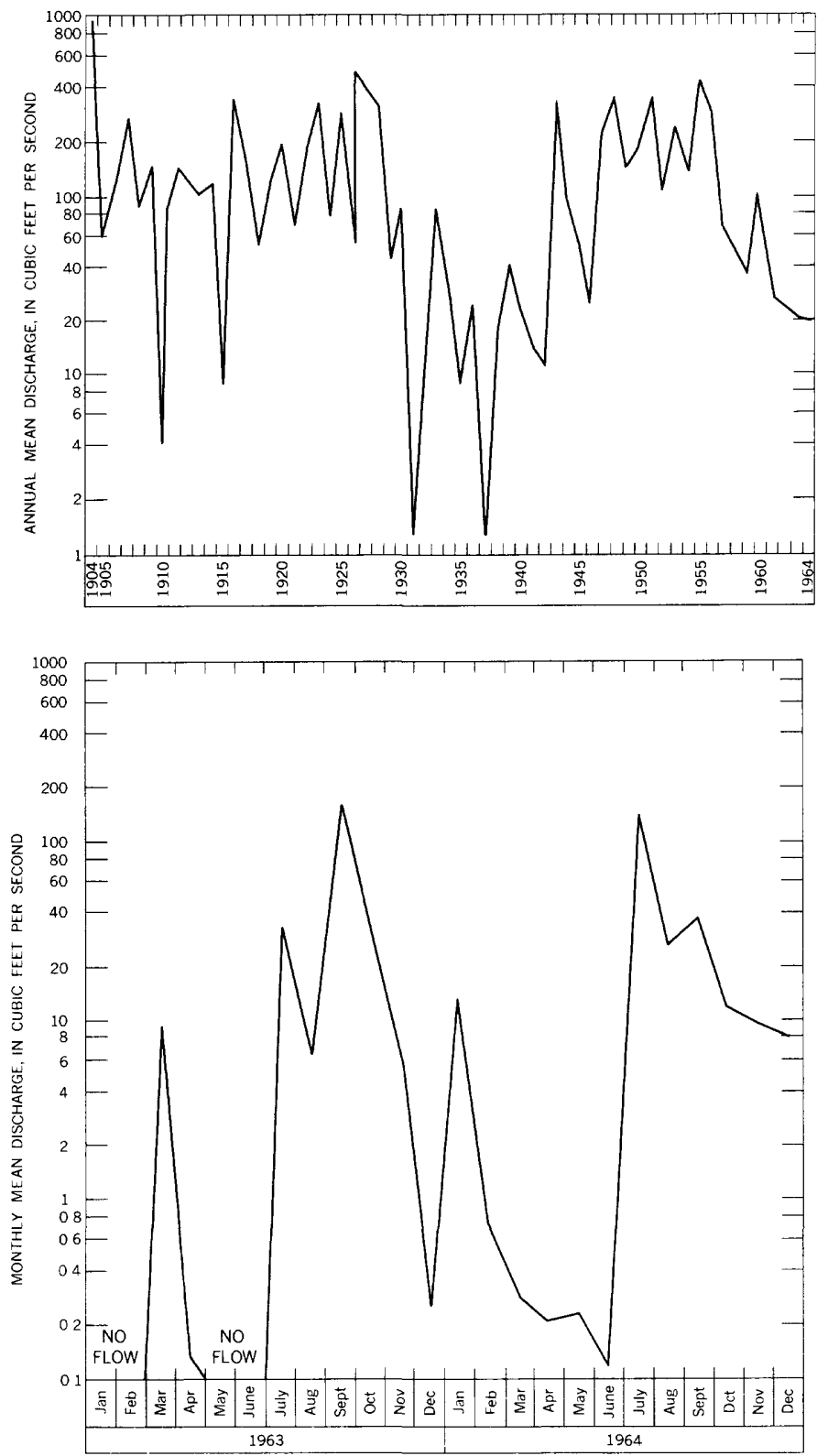

Figure 3.-Annual mean discharge of the Souris River, 1904-64, and monthly mean discharge, October 1962-September 1964 
State College. The city has grown rapidly in the last few yearsthe population was 16,577 in $1940,20,032$ in 1950, and 30,604 in 1960. The rapid growth can be attributed to increasing importance of the city as a key trading center and to the installation of the Minot Air Force Base, 14 miles north of town.

\section{PRINCIPLES OF GROUND-WATER HYDROJOGY}

The definition and principles of ground-water hydrology are commonly not well known to individuals outside the field of hydrology. The following section defines several hydrologic terms and principles so that the interested layman may better understand the information in this report.

In general, ground water moves from points of high elevation to points of low elevation-that is, from areas of recharge to areas of discharge. The elevation to which water will rise in the casing of wells that penetrate an artesian aquifer is called the piezometric surface. This is an imaginary surface that is mapped by determining the elevation of the water level in a network of wells. This surface, then, is represented on maps by contours that connect points of equal elevation. Ground water moves downgradient and perpendicular to the contours.

The texture and sorting of the rock components control, to a large degree, the two major water-bearing properties of an aquifer-its porosity and permeability. Porosity of a rock is determined by the size and number of voids, or interstices, as compared to tlo total rock volume and is expressed as a percentage. Generally a porosity of more than 20 percent is considered to be high, and a porosity less than 5 percent, low. The permeability of an aquifer is its capacity to transmit water. A permeable rock is also porous, but high porcsity does not necessarily indicate high permeability.

An aquifer drained by force of gravity will not yield all the water contained in the voids because of molecular attraction between the water and the rock particles. The quantity of water yielded by gravity drainage is called the specific yield, which is expressed as a percentage. The amount of water retained in the aquifer is called the specific retention, which is also expressed as a percentage. The specific yield plus the specific retention equals the porosity. The specifs retention increases as the grain size decreases because of the greater total surface area of the grains. For example, the total porosity of clay may be high, but the specific retention is very high, and the sfecific yield, conversely, is very low. Accordingly, specific yield is considered to be synonymous with the term "effective porosity," or "practical porosity."

The coefficient of permeability, in meinzer units, is the rate, in gallons per day, at which water will flow through a cross-sectional area of 
1 square foot under a hydraulic gradient of 1 foot per foot at a temperature of $60^{\circ} \mathrm{F}$. Horizontal permeability, in general, is greater than vertical permeability. Permeabilities may be determined by either laboratory or field methods.

Transmissibility $(T)$ is expressed as the rate of flow of water, in gallons per day, through a vertical strip of the aquifer 1 foot wide extending the full saturated thickness of the aquifer under a hydraulic gradient of 100 percent-that is, a 1-foot drop in head in 1 foot of flow distance. The product of the permeability $(P)$ and the saturated thickness $(m)$ of an aquifer equals the transmissibility, $T=P m$.

The relocity of ground-water movement can be determined by the formula :

$$
v=P I
$$

where

$v=$ velocity in feet per day,

$P=$ coefficient of permeability, in gallons per day per square foot, and,

$I=$ gradient, in feet, per foot.

Total volume of flow is the major factor in most ground-water problems, and it can be determined by the formula:

$$
Q=P I A, \text { or } Q=T I W .
$$

where $P, I$, and $T$, are as previously described, and

$Q=$ discharge, in gallons per day,

$A=$ area of flow cross section, in square feet, and

$W=$ width of flow cross section, in feet.

Areas of high transmissibility allow rapid movement of ground water and will yield large quantities of water to wells. Transmissibilities can be determined by either laboratory or field methods. The most accurate method for determining transmissibility is that of an aquifer test in which a well is pumped and the drawdown and the rate of water-level recovery in the pumped well and in adjacent observation wells are measured. Such data are then plotted and analyzed. However, the calculated values of transmissibility from each aquifer test are accurate only for the conditions of the tes ${ }^{+}$, and these values may change under conditions of longer periods of pumping and different quantities of discharge.

The coefficient of storage $(S)$ is the volume of water an aquifer will release from,-or take into, storage per unit surface area of the aquifer 
per unit change in the component of head perpendicular to that surface. The coefficient of storage in an artesian aquifer differs considerably from that in a water-table aquifer. Storago in an artesian aquifer depends on the compressibility of the ro ${ }^{\circ} \mathrm{k}$ material and of the included water. The storage coefficient in a water-table aquifer can be attributed to gravity drainage and, to a lesser extent, to compressibility of the rock material and of the included water. As a result, the coefficient of storage in an artesian, or confined, aquifer is characteristically very small, the order of magnitude being $0.00001-0.001$. This small storage coefficient indicates that large pressure changes throughout extensive areas are necessary for the aquifer to yield large supplies of water. In aquifers where the water level is drawn below the confining layer during pumping, "ler.ky artesian conditions" may exist. Leaky artesian conditions indicate that the aquifer is under confined conditions before pumping and approaches unconfined conditions as the water level lowers during pumping. The coefficient of storage in a leaky artesian aquifer ranges from about 0.001 to 0.05 . The storage coefficient of a water-table, or unconfined, aquifer is commonly referred to as specific yield; it is considerably larger, generally ranging from 0.05 to 0.30 .

Large storage capacity in a water-table aquifer allows the cone of depression (caused by pumping) to spread outward more slowly than it would spread under similar conditions of pumping in an artesian aquifer. Thus, under similar conditions, more water can be removed from a water-table aquifer than from an artesian aquifer, and its removal will cause less interference in adjacent wells owing; to overlapping cones of depression.

The specific capacity of a well is its rate of yield in gallons per minute per foot of drawdown. Drawdown in a well increases with continued pumping, generally at a diminishing rate, and the resulting specific capacity calculations are only approximate. Determination of the specific capacity of a well is convenient after a 1-day pumping period. For example, a well that will yield $500 \mathrm{gpm}$ (gallons per minute) and have a drawdown of 25 feet has a specific capacity of $\frac{500 \mathrm{gpm}}{25 \mathrm{ft}}=20 \mathrm{gpm}$ per foot of drawdown for the period pumped. Low specific capacity results in low yield, large pumping lifts, and, consequently, high production costs. The specific capacity depends on transmissibility of the aquifer and efficiency of the well.

Wells that are not screened the entire thickness of the aquifer are known as partially penetrating wells. The lines of waterflow in a partially penetrating well are longer than in a fully penetrating well because the water must travel up or down to the screen. Because the 
water travels additional distance to the well screen, a greater frictiona] resistance to waterflow is caused, which in turn causes a greater drawdown. The drawdown is greatest near the pumping well and, theoretically, becomes negligible away from the well at a distance equal to about twice the saturated thickness of the aquifer. Aquifer-test formulas are based on the assumption that the wells penetrate the full thickness of the aquifer, and corrective factors should be appliad to any data obtained from partially penetrating wells.

While a well is being pumped, the cone of depression in the water table or in the piezometric surface expands and deepens. The lowering of the water level is known as drawdown. Shape of the cone of depression depends mainly on the coefficients of transmissibility and storage of the aquifer. The rate of pumping causes a corresponding variation in the depth of the cone; the coefficient of storage controls the radial spread of the cone. The transmissibility affects the $r$ dius and the depth of the cone. Where cones of depression of two or more wells overlap, the resulting interference causes a loss in yield or in an increase in drawdown in each well. Also, well discharge can decline where interference occurs, if the rate of pumping remains constant.

\section{TERTIARY DEPOSITS AND THEIR WATER-BEARI ${ }^{\top} G$ PROPERTIES}

Rocks of Tertiary age in the Minot area belong to the Fort Union Formation. The formation is composed of three members, whicl are, in descending order, the Tongue River, Cannonball, and Ludlow I Tembers. The Tongue River Member, which composes the bedrock in the Minot area, is made up of continental deposits of clay, sandstone, and lignite; it is about 255 feet thick.

The lignite and fine-grained sandstone beds in the Fort Union Formation are the sources of water for wells and springs. In many areas the lignite beds are underlain by clay that restricts the downward movement of ground water. Consequently, ground water accumulates and moves laterally in the lignite beds to points of discharge. I Tany springs in the Souris River valley issue at the contact of a bed of lignite with the underlying clay.

Although flowing wells are common in the Fort Union Formation, they generally do not yield large amounts of water. Probably the wells flow because of considerable amounts of dissolved gas in the water as well as because of artesian pressure. The gas probably originates in the lignite.

Water suitable for most domestic purposes can be produced from the Fort Union Formation in some places. In many places, however, the water is undesirable for domestic uses because it has a strong "alkali" taste resulting mainly from its sodium bicarbonate content. It is 
soft and is commonly high in dissolved solids. The quality of water from this formation has a wide range but is apparently not related to depth. Water pumped directly from fractured lignite may have a brown color, as well as a strong sulfur odor. The geochemistry of the water is probably related to the depositional history of the waterbearing sediments. A zone slightly more permeable tl an adjacent deposits would permit more rapid movement and leaching of the sediments by circulating ground water. The removal of readily soluble materials from this zone would make it possible for subsequent circulating ground water to pass through the zone without being changed in chemical composition.

Chemical analyses of water samples from selected wells that tap the Fort Union Formation were made by the State Laboratories Department, Bismarck, N. Dak. Analytical results of samples from three selected wells, given in parts per million except where indicated, are as follows:

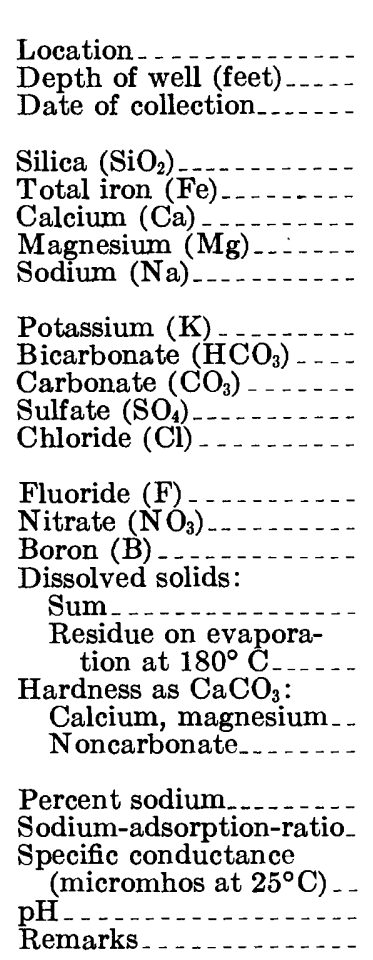

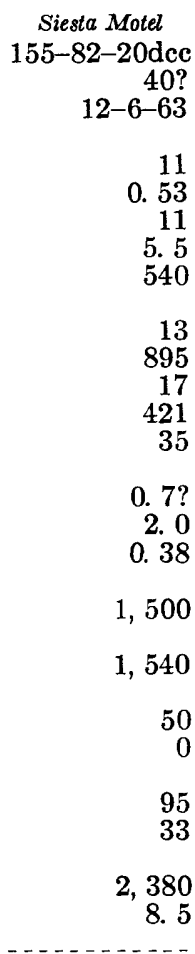

\begin{tabular}{rr} 
W. Lashkowski & \multicolumn{1}{c}{ J.Watson } \\
$156-83-5 \mathrm{bb}$ & $156-83-12 \mathrm{dc}$ \\
580 & 290 \\
$9-12-47$ & $9-12-47$ \\
7.0 & 7.0 \\
0.32 & 0.62 \\
10 & 12 \\
5.7 & 3.7 \\
1,050 & 718 \\
11 & 8.8 \\
936 & 1,280 \\
0 & 0 \\
1.4 & 137 \\
1,120 & 295 \\
0.3 & 0.3 \\
2.2 & 10 \\
2.7 & 1.3
\end{tabular}

500

, 540

2,670

1,820

50

95

33 


\section{QUATERNARY DEPOSITS AND THEIR WATER-BEAPING PROPERTIES}

Glacial drift includes all glacial ice deposits, as well as river, stream, and lake deposits, that were directly associated with the glacier. Till was deposited directly by glacial ice and consists of a heterogeneous mixture of clay, silt, sand, gravel, and boulders in which clay and silt predominate. Glaciofluvial material was deposited by glacial melt water and consists predominantly of sand and gravel. Alluvium consists of clay, silt, sand, and gravel deposited by running water that was not directly derived from, or otherwise associated with, glaciers.

Glacial drift and alluvium mantle the Minot area, except in a few small areas where bedrock crops out (pl. 1). The total thickress of the glacial material is controlled by the topography of the betrock. The thickness is more than 450 feet beneath the upland surface along the courses of former stream channels. However, in most places the drift averages about 100 feet thick. These deposits are more than 250 feet thick in the Souris River valley near the central port of Minot.

Several gravel pits in the vicinity of Minot (pl. 1) are in riverterrace deposits. River-terrace deposits normally represent former flood plains. The deposits appear uplifted because of downcutting in the valley subsequent to the deposition of the terrace. Four sard and gravel deposits in the Souris River valley in the vicinity of Minot are mapped as river-terrace deposits (pl. 1), but their characteristics do not entirely conform to those of similar river-terrace deposits in other areas.

Large gravel exposures at the west end of the city (155-82-21), in the center of the city (155-82-23 and 24), and southeast of tro city (155-82-32) may represent river-terrace deposits or kame-terrace remnants. These features are composed mostly of sand and gravel but contain boulders that are more than 7 feet in diameter. The Minot Sand and Gravel Co. pit at the west end of the city is more than 70 feet deep. The lower part of the pit is dug predominantly in sand that is massively crossbedded in places. The upper part is in poorly sorted sand and gravel. Locally some zones show graded bedding and cut and fill features. Both parts of the pit show collapse structures near the outer boundaries. The sand increases in thickness northeastward.

Ice-contact deposits were formed by melt water flowing within, or adjacent to, the glacial ice. Kame terraces are ice-contact deposits generally consisting of sand and gravel that were laid down by streams flowing between the glacier and the valley wall during deglaciation. Is the ice supporting the valleyward side of the kame terraces melted, 
this side of the terraces collapsed, and a contorted structure was produced.

A kame-terrace deposit forms the valley wall in the northwest part of Minot (pl. 1). This particular deposit consists largely of sand, although some thin layers of gravel are locally present. Many of the layers have been deformed by faulting or folding. Another deposit, which consists predominantly of sand and gravel, covers a large area near the southeast edge of Minot (155-82-30). Apparently this deposit was overridden during the last glacial advance because it is overlain by till. Lemke (1960, p. 55) suggested that this deposit represents an overridden kame terrace. It appears, however, to represent glaciofluvial material and probably indicates the former course of a melt-water channel. This deposit may be a continuation of the North Hill aquifer that was penetrated in several test $\mathrm{r}$ oles in the northern part of Minot.

\section{NORTH HILL AQUIFER}

The North Hill aquifer is a shallow glaciofluvial deposit enveloped by glacial till in the uplands at the north end of Minot (pl. 2). The aquifer is artesian and underlies more than 3 square miles. It ranges in thickness from 1 to 30 feet, and its top ranges in depth from 26 to 66 feet below land surface. The aquifer consists of reddish-brown, iron oxide coated coarse sand and fine to medium gravel.

The gradient of the water level in the North Hill aquifer is to the south, and the aquifer discharges in a zone of springs and seeps along the north wall of the Souris River valley (pl. 2). A spring issuing from the North Hill aquifer in 155-83-14bca has formed a lake, and an overflow stream from the lake has a discharge of more than 14 gallons per minute.

The North Hill aquifer also provides small quantities of water to six domestic and industrial wells. The deepest well $(155-83-2 \mathrm{dd})$ is reportedly 60 feet deep, and the shallowest well (155-83-2dad) 32 feet deep. The average depth of the wells is 47 feet.

Water from the North Hill aquifer is high in total dissc'ved solids, hardness, and sulfate contents. Nevertheless, it is used for industrial and domestic supplies.

The following list gives the chemical analyses of water from a test hole drilled in the North Hill aquifer and from a spring that issues from it. Analyses were made by the State Laboratories I'spartment, Bismarck, N. Dak., and results are given in parts per million except where indicated. 


\begin{tabular}{|c|c|c|c|}
\hline & $\begin{array}{l}\text { U.S. Public } \\
\text { Health Service } \\
\text { limits (1962) }\end{array}$ & Test hole s237 & Spring \\
\hline $\begin{array}{l}\text { Location } \\
\text { Dept of well (feet) } \\
\text { Date of collection } \\
\text { Temperature }\left({ }^{\circ} \mathrm{F}\right)\end{array}$ & 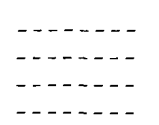 & $\begin{array}{r}155-83-1 \mathrm{ccc} \\
30 \\
8-27-65 \\
48\end{array}$ & $\begin{array}{r}155-83-14 d^{\prime} d d \\
\text { Surface } \\
1058\end{array}$ \\
\hline $\begin{array}{l}\text { Silica }\left(\mathrm{SiO}_{2}\right) \\
\text { Total iron }(\mathrm{Fe}) \\
\text { Calcium }(\mathrm{Ca}) \\
\text { Magnesium }(\mathrm{Mg}) \\
\text { Sodium }(\mathrm{Na})\end{array}$ & $\begin{array}{l}-1 \\
-1 \\
-1\end{array}$ & $\begin{array}{r}16 \\
0.08 \\
488 \\
151\end{array}$ & 75 \\
\hline $\begin{array}{l}\text { Potassium }(\mathrm{K}) \\
\text { Bicarbonate }\left(\mathrm{H} \overline{\mathrm{CO}} \mathrm{O}_{3}\right)_{\ldots}\end{array}$ & & 380 & 0 \\
\hline Carbonate $\left(\mathrm{CO}_{3}\right)$ & & & 40 \\
\hline $\begin{array}{l}\text { Sulfate }\left(\mathrm{SO}_{4}\right) \\
\text { Chloride }(\mathrm{Cl})\end{array}$ & $\begin{array}{l}250 \\
150\end{array}$ & $\begin{array}{r}2,300 \\
32\end{array}$ & $\begin{array}{r}482 \\
0\end{array}$ \\
\hline $\begin{array}{l}\text { Fluoride }(\mathrm{F}) \\
\text { Nitrate }\left(\mathrm{NO}_{3}\right) \\
\text { Boron }(\mathrm{B})\end{array}$ & 1.2 & $\begin{array}{r}0.4 \\
4.7 \\
0.42\end{array}$ & $\begin{array}{r}0.2 \\
0.43 \\
\text { Trace }\end{array}$ \\
\hline $\begin{array}{l}\text { Dissolved solids: } \\
\text { Sum } \\
\text { Residue on evaporation }\end{array}$ & 500 & 3,600 & 1,019 \\
\hline $\begin{array}{l}\text { at } 180^{\circ} \mathrm{C} \\
\text { Hardness as } \mathrm{CaCO}_{3} \text { : }\end{array}$ & & 3,430 & $@ 24$ \\
\hline $\begin{array}{l}\text { Calcium, magnesium } \\
\text { Noncarbonate }\end{array}$ & $---1-1$ & $\begin{array}{l}1,840 \\
1,530\end{array}$ & 568 \\
\hline $\begin{array}{l}\text { Percent sodium } \\
\text { Sodium-adsorption-ratio-- } \\
\text { Specific conductance }\end{array}$ & -- & $\begin{array}{r}33 \\
4.3\end{array}$ & -- \\
\hline pH......... & & 7.6 & 2 \\
\hline
\end{tabular}

To determine the areal extent, thickness, and hydraulic characteristics of the North Hill aquifer, additional test holes are needed. The high concentration of sulfate in the water, the abrupt changes in thickness, and the apparent lack of natural recharge areas suggest that this aquifer does not have good potential for development.

\section{SOUTH HILL AQUIFER}

The South Hill aquifer trends east-west near the south end of Minot. The aquifer, which consists of sand and gravel, is in a buried channel, and the water is under artesian pressure. The buried channel is about 1 mile wide and at least 2 miles long; it is 451 feet deep in test hole 2239 (pl. 2). The channel probably represents a former valley of the Souris River that was blocked by drift during an advance of glacial ice.

The aquifer is not uniform in thickness nor in areal extent. As much as 67 feet of sand and gravel was penetrated in the lower part of test hole 2240 ( $35 \mathrm{ft}$ from depths 154 to 189 , and $32 \mathrm{ft}$ from depths 356 to 388 ). However, in test hole 2239, only 9 feet of sand and gravel (at depths 103-109 ft and 148-151 ft) was penetrated. 
Eleven industrial and domestic wells produce small quantities of water from the South Hill aquifer. The deepest well (155-82-31 baa) has a reported depth of 338 feet and the shallowest well (155-82$31 \mathrm{dca})$ has a reported depth of 170 feet. The average denth of wells in the South Hill aquifer is 259 feet.

Although accurate water-level measurements are not available, water levels are reportedly 190-231 feet below land surface.

Water from the South Hill aquifer has a high content of total dissolved solids, hardness, iron, and sulfate. The following list gives the chemical analyses of water from three wells tapping the aquifer. Analyses were made by the State Laboratories Department, Bismarck, N. Dak., and results are given in parts per million except where indicated.

\begin{tabular}{|c|c|c|c|c|}
\hline & $\begin{array}{l}\text { U.S. Public } \\
\text { Health Service } \\
\text { limits (1962) }\end{array}$ & $\begin{array}{l}\text { North Dakota State } \\
\text { Highway Department } \\
\text { weigh station }\end{array}$ & $\begin{array}{l}\text { Jordahl Animal } \\
\text { Hospital }\end{array}$ & C. J. Drawz \\
\hline $\begin{array}{l}\text { Location } \\
\text { Depth of well (feet) } \\
\text { Date of collection } \\
\text { Temperature }\left({ }^{\circ} \mathrm{F}\right)\end{array}$ & 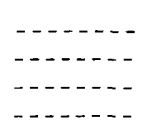 & $\begin{array}{r}155-82-30 \text { dcc } \\
257 \\
8-20-65 \\
54\end{array}$ & $\begin{array}{r}155-83-35 \mathrm{aad} \\
215 \\
8-20-65\end{array}$ & $\begin{array}{r}155-83-36 \mathrm{bc} \\
276 \\
1958 \\
-\end{array}$ \\
\hline $\begin{array}{l}\text { Silica }\left(\mathrm{SiO}_{2}\right) \\
\text { Total iron }(\mathrm{Fe}) \\
\text { Calcium }(\mathrm{Ca}) \\
\text { Magnesium }(\mathrm{Mg}) \\
\text { Sodium }(\mathrm{Na})\end{array}$ & $\begin{array}{r}0.3 \\
-\cdots-1 . \\
-\cdots\end{array}$ & $\begin{array}{r}17 \\
5.2 \\
155 \\
56 \\
162\end{array}$ & $\begin{array}{r}18 \\
0.80 \\
193 \\
71 \\
298\end{array}$ & $\begin{array}{r}4.9 \\
151.2 \\
75.4\end{array}$ \\
\hline $\begin{array}{l}\text { Potassium }(\mathrm{K}) \\
\text { Bicarbonate }\left(\mathrm{H}^{2} \mathrm{CO}_{3}\right) \\
\text { Carbonate }\left(\mathrm{CO}_{3}\right) \\
\text { Sulfate }\left(\mathrm{SO}_{4}\right) \\
\text { Chloride }(\mathrm{Cl})\end{array}$ & $\begin{array}{r}250 \\
150\end{array}$ & $\begin{array}{r}11 \\
692 \\
0 \\
285 \\
87\end{array}$ & $\begin{array}{r}11 \\
941 \\
0 \\
620 \\
13\end{array}$ & $\begin{array}{r}1,020 \\
0 \\
390 \\
68.6\end{array}$ \\
\hline $\begin{array}{l}\text { Fluoride }(\mathrm{F}) \\
\text { Nitrate }\left(\mathrm{NO}_{3}\right) \\
\text { Boron }(\mathrm{B})\end{array}$ & $\begin{array}{r}1.2 \\
45\end{array}$ & $\begin{array}{r}0.4 \\
0.7 \\
0.18\end{array}$ & $\begin{array}{r}0.4 \\
2.9 \\
0.25\end{array}$ & $\begin{array}{r}0.2 \\
0 \\
0\end{array}$ \\
\hline $\begin{array}{l}\text { Dissolved solids: } \\
\text { Sum } \\
\text { Residue on }\end{array}$ & 500 & 1,120 & 1,690 & 2,005 \\
\hline $\begin{array}{c}\text { evaporation at } \\
180^{\circ} \mathrm{C}_{-} \\
\text {Hardness as } \mathrm{CaCO}_{3} \text { : }\end{array}$ & -- & 1,040 & 1,730 & \\
\hline $\begin{array}{l}\text { Calcium, } \\
\text { magnesium } \\
\text { Noncarbonate } \ldots\end{array}$ & - & $\begin{array}{r}615 \\
48\end{array}$ & $\begin{array}{r}775 \\
4\end{array}$ & 687 \\
\hline $\begin{array}{l}\text { Percent sodium } \\
\text { Sodium-_-_- - - }\end{array}$ & $\ldots$ & 36 & 45 & \\
\hline $\begin{array}{l}\text { Specific conductance } \\
\text { (micromhos at } \\
25^{\circ} \mathrm{C} \text { ) } \\
\mathrm{pH}\end{array}$ & 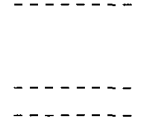 & $\begin{array}{r}1,670 \\
8.2\end{array}$ & $\begin{array}{r}2,360 \\
8\end{array}$ & $\cdots$ \\
\hline
\end{tabular}

To determine the areal extent, thickness, and hydraulic characteristics of the South Hill aquifer additional test holes are required. The poor quality of the water and the abrupt changes in thickness of the 
sand and gravel, as well as the deep water level may exclude the South Hill aquifer from extensive development.

\section{SUNDRE BURIED-CHANNEL AQUIFER}

In the Souris River valley $31 / 2$ miles southeast of Minot, test hole 2214 (155-82-4aad) penetrated 193 feet of saturated sand and gravel in a terrace along the north edge of the valley (pl. 2). Although its origin is not definitely known, the deposit probably represents a former river channel that is now buried in most places by glacial drift. The channel is 233 feet deep at the test-hole site. This aquifer, which is exposed at land surface in some places, consists of fine to coars? sand and fine to medium gravel and contains abundant lignite chips.

Near test hole 2214, the Souris River flows adjacent to the south edge of the Sundre buried-channel aquifer. The river probably provides recharge to the aquifer during high river stages and receives effluent seepage from the aquifer during low stages. The water level in the aquifer is about 14.5 feet below land surface.

Apparently no wells have been drilled to this aquifer. Although more information on the thickness, permeability, and quality of water in the aquifer is needed, it appears to be a potential source of large quantities of water. The boundaries shown on plate 2 were inferred from topography and adjacent outcrops.

The quality of the water in the Sundre buried-channel aquifer seems to be much better than that of the water in the North Hill and South Hill aquifers. In fact, quality is better than that of water in several of the Minot municipal wells. Water from test hole 2214 was analyzed by the State Laboratories Department, Bismark, N. Dak. Resilts of the analyses, given in parts per million except where indicated, are as follows :

\begin{tabular}{|c|c|c|}
\hline & $\begin{array}{l}\text { U.S. Public } \\
\text { Health Service } \\
\text { limits (1962) }\end{array}$ & Test hole $2: 14$ \\
\hline $\begin{array}{l}\text { Location } \\
\text { Depth of well }(\mathrm{feet}) \\
\text { Date of collection } \\
\text { Temperature }\left({ }^{\circ} \mathrm{F}\right)\end{array}$ & 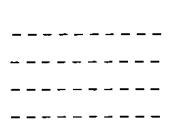 & $\begin{array}{r}154-82-4 \text { aad } \\
233 \\
11-15-63 \\
42\end{array}$ \\
\hline $\begin{array}{l}\text { Silica }\left(\mathrm{SiO}_{2}\right) \\
\text { Total iron }(\mathrm{Fe}) \\
\text { Calcium }(\mathrm{Ca}) \\
\text { Magnesium }(\mathrm{Mg}) \\
\text { Sodium }(\mathrm{Na})\end{array}$ & 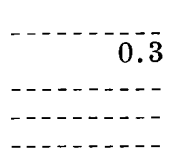 & $\begin{array}{r}22 \\
0.35 \\
109 \\
28 \\
137\end{array}$ \\
\hline $\begin{array}{l}\text { Potassium }(\mathrm{K}) \\
\text { Bicarbonate }\left(\mathrm{HCO}_{3}\right) \\
\text { Carbonate }\left(\mathrm{CO}_{3}\right) \\
\text { Sulfate }\left(\mathrm{SO}_{4}\right)_{2} \\
\text { Chloride }(\mathrm{Cl})_{-}\end{array}$ & $\begin{array}{r}250 \\
150\end{array}$ & $\begin{array}{r}9.6 \\
569 \\
0 \\
195 \\
17\end{array}$ \\
\hline
\end{tabular}




\begin{tabular}{|c|c|c|}
\hline & $\begin{array}{c}\text { U.S. Public } \\
\text { Health Service } \\
\text { limits (1962) } \\
\text {-Con. }\end{array}$ & $\begin{array}{l}\text { Test hole } 2214 \\
\text { - Con. }\end{array}$ \\
\hline Fluoride (F) & 1.2 & 0.5 \\
\hline Nitrate $\left(\mathrm{NO}_{3}\right)_{1} \ldots \ldots \ldots$ & 45 & 1.5 \\
\hline Boron (B) - & -1 & 0 \\
\hline Dissolved solids: & & \\
\hline Sum & 500 & 800 \\
\hline $\begin{array}{l}\text { Residue on evaporation at } 180^{\circ} \mathrm{C} \ldots \\
\text { Hardness as } \mathrm{CaCO}_{3} \text { : }\end{array}$ & -- & 800 \\
\hline Calcium, magnesium -- & --- & 388 \\
\hline Noncarbonate & --- & 0 \\
\hline sodi & -..- & 43 \\
\hline $\begin{array}{l}\text { Sodium-adsorption-ratio } \\
\text { Specific conductance (micromhos at }\end{array}$ & -. & 3.0 \\
\hline $\begin{array}{c}\text { Specific conductance (micromhos at } \\
\left.25^{\circ} \mathrm{C}\right)\end{array}$ & & 1,300 \\
\hline $\mathrm{pH}_{-}$ & - & 8.1 \\
\hline
\end{tabular}

\section{LOWER SOURIS AQUIFER}

The lower Souris aquifer is an artesian system that extends downstream or southeastward, from Minot for more than 6 miles (pl. 2). The aquifer is confined to the Souris River valley, and the sand and gravel of the aquifer (which are underlain and overlain by glacial till) represent a buried valley train. The aquifer generally ranges in thickness from 10 feet to 79 feet, and the top ranges from 19 to 83 feet below land surface.

The water-level gradient in the lower Souris aquifer is northeastward, toward Minot. The gradient in the southeastern part of the aquifer is less than 0.25 foot per mile between test holes 2212 and 2213 but is more than 7 feet per mile between test holes 2213 and 2216 because of discharge to the adjoining Minot aquifer.

The lower Souris aquifer is tapped by only one large-yield well (154-82-3cac), which is at the Bison Generating Plant. The well has a capacity of $500 \mathrm{gpm}$ (gallons per minute), but it is soldom used. It is 92 feet deep and, after pumping 420 gpm for 24 hours, has a specific capacity of $78 \mathrm{gpm}$ per foot of drawdown. The transmissibility of the aquifer in the vicinity of the well is about $156,000 \mathrm{gpd}$ per ft (gallons per day per foot).

Only nine test holes penetrate the Lower Souris aquifer, and consequently, little is known of the changes in thickness of the sand and gravel. Near the walls of the river valley, however, the aquifer may be thin or absent; and it may be absent locally in the central part of the valley also.

Water in the lower Souris aquifer is of suitable quality for most domestic and industrial uses. It is hard, and its high content of iron will stain clothes and fixtures, but its concentrations of other chemical 
components are generally much lower than those of water in the North Hill and South Hill aquifers and in the Sundre buried-channel aquifer or parts of the Minot aquifer. Listed next are the rerults of chemical analyses of water from five test holes and wells that tap the lower Souris aquifer. Analyses were made by the State Laboratories Department, Bismarck, N. Dak., and results are given in parts per million except where indicated.

\begin{tabular}{|c|c|c|c|c|c|c|}
\hline & $\begin{array}{c}\text { U.S. Public } \\
\text { Health } \\
\text { Service } \\
\text { limits } \\
(1962)\end{array}$ & $\begin{array}{l}\text { Test hole } \\
\quad 2213\end{array}$ & $\begin{array}{l}\text { Test hole } \\
\text { 2216 }\end{array}$ & $\begin{array}{l}\text { Test hole } \\
2215\end{array}$ & $\begin{array}{c}\text { Bison Plant } \\
\text { observation } \\
\text { well } 5\end{array}$ & $\begin{array}{l}\text { Eison Plant } \\
\text { observation } \\
\quad \text { well } 2\end{array}$ \\
\hline $\begin{array}{l}\text { Location } \\
\text { Depth of well (feet) }\end{array}$ & $--\cdot$ & $154-82-4 a b a$ & $\begin{array}{r}155-82-19 \mathrm{dbd} \\
107\end{array}$ & $155-82-29 b c b$ & $154-82-3 \mathrm{cba}$ & $\begin{array}{r}154-82-3 c d b \\
86\end{array}$ \\
\hline $\begin{array}{l}\text { Depth of well (teet) } \\
\text { Date of collection }\end{array}$ & $\cdots$ & $\begin{array}{r}120 \\
11-14-63\end{array}$ & $\begin{array}{r}10 t \\
11-19-63\end{array}$ & $\begin{array}{r}105 \\
11-15-63\end{array}$ & $8-27-65$ & $\begin{array}{r}86 \\
8-26-65\end{array}$ \\
\hline Temperature $\left({ }^{\circ} \mathrm{F}\right)$ & $\cdots$ & & 47 & & 48 & \\
\hline Silica $\left(\mathrm{SiO}_{2}\right) \ldots$ & & 23 & 21 & 22 & 18 & 17 \\
\hline Total iron (Fe) & 0.3 & 0.28 & 0.76 & 1.1 & 0.96 & 1.5 \\
\hline Calcium (Ca) & -..- & 48 & 55 & 57 & 85 & 96 \\
\hline Magnesium (Mg). & -........ & 1.9 & 14 & 31 & 26 & 26 \\
\hline$(\mathrm{Na})$ & $\ldots$ & 165 & 261 & 237 & & 88 \\
\hline Pota & & 10 & 12 & 14 & 174 & 7.1 \\
\hline Bicarbonate $\left(\mathrm{HCO}_{3}\right)$ & -......... & 451 & 645 & 583 & 600 & 480 \\
\hline (CO & & 10 & 7 & 0 & 0 & \\
\hline Sulfa & 250 & 165 & 133 & 145 & 134 & 135 \\
\hline Chloride (Cl)- & 150 & 14 & 79 & & 40 & 11 \\
\hline Fluoride $(\mathrm{F})$. & 1.2 & 0.3 & 0.5 & 0. & 0.4 & 0.3 \\
\hline$\left(\mathrm{NO}_{3}\right)$ & 45 & 3. 0 & 3. 0 & 2.0 & 8.6 & 5. 4 \\
\hline Boron (B) .... & & 0 & 0 & 0 & 0 & 0.14 \\
\hline Dissolved solids: & & & & & & \\
\hline Sur & 500 & 679 & 904 & 936 & 783 & 623 \\
\hline Residue on & & $f 74$ & 949 & 090 & 74 & 621 \\
\hline $\begin{array}{l}\text { tion at } 180^{\circ} \mathrm{C}_{---} \\
\text {Hardness as } \mathrm{CaCO}_{3} \text { : } \\
\text { Calcium, mag- }\end{array}$ & & 674 & 949 & 990 & 740 & 621 \\
\hline ne & -. & 200 & 196 & 268 & 318 & 348 \\
\hline Non & & 0 & 0 & 0 & 0 & \\
\hline Percent & -.. & 63 & & 64 & 54 & 35 \\
\hline Sodiu & & & & & & \\
\hline $\begin{array}{l}\text { ratio } \\
\text { Specific conductance }\end{array}$ & -.. & 5.1 & & 6.3 & 4. 2 & 2.1 \\
\hline $\begin{array}{l}\text { (micromhos at } \\
25^{\circ} \mathrm{C} \text { ) } \\
\mathrm{pH}\end{array}$ & & $\begin{array}{r}1,090 \\
8.4\end{array}$ & $\begin{array}{r}1,510 \\
8.3\end{array}$ & $\begin{array}{r}1,610 \\
8.1\end{array}$ & $\begin{array}{r}1,190 \\
7.9\end{array}$ & $\begin{array}{l}977 \\
8.3\end{array}$ \\
\hline
\end{tabular}

Natural recharge to the aquifer probably takes place by seepage from the Souris River, from adjacent glacial drift, and, in places from the Fort Union Formation. Little or no natural recharge is supplied from the Sundre buried-channel aquifer. The lower Souris aquifer discharges water to the Minot aquifer by underflow. The quantity of water flowing northwestward through a cross section perpenticular to the long axis of the aquifer at test hole 2216 is probably obout 1 mgd (million gallons per day).

The lower Souris aquifer is a potential source for large quentities of good quality water, but additional test drilling is necessary to determine the areal extent and the thickness of the aquifer. 


\section{NORTHWEST BURIED-CHANNEL AQUIFER}

The northwest buried-channel aquifer is a deeply buried glaciofluvial deposit of sand and gravel that locally contains large amounts of clay. The aquifer extends northwestward from the central part of Minot, but the course of the channel is not well known (pl. 2). The channel may be more than $11 / 2$ miles wide, but the aquifer, which is artesian, is probably less than 1 mile wide. The channel has no surface expression.

Four test holes (Nos. 2218, 2233, 2234, and 2367) were drilled in the northwest buried-channel aquifer. A thickness of 105 feet of saturated sand and gravel was penetrated in test hole 2218 at depths of 220-325 feet; the water level in the test hole was about 220 feet below land surface. A thickness of only 27 feet of gravel was penetrated in test hole 2367 at depths of $235-262$ feet; the water level was about 29 feet below land surface. Test holes 2233 and 2234, or. the Minot State College campus, penetrated the north west buried-channel aquifer near its connection with the Minot aquifer. The water levels in these test holes, as well as in the Minot State College well, were about 76 feet below land surface. The water levels are influenced by pumping of city wells $5,6,9$, and 10 , indicating an interconnection of the Minot and northwest buried-channel aquifers.

These wells and test holes are believed to penetrate both the northwest buried-channel aquifer and the shallower, Minot aquifer. This belief is based on the facts that, compared with other municipal wells, (1) these wells are deeper, (2) water-level interference occurs between these wells during pumping, and (3) the water from the wells has a higher chloride content.

The lithologic logs of the well and test holes on the college campus (pl. 2) show that marked changes in lithology and thickness occur within short distances in the northwest buried-channel aquifer. None of these wells are more than 400 feet apart. Also a stock well in 155-83-3cbc penetrates the entire aquifer, but the driller reported that the well produces only about $15 \mathrm{gpm}$.

The water-level gradient in the aquifer is southeastward towards the Minot aquifer. The gradient between test holes 2367 and 2218 is nearly 113 feet per mile, which is abnormally steep. T1 a gradient between test holes 2218 and 2233 is about 23 feet per mile.

The quantity of water flowing southeastward through cross section $A-A^{\prime}$ (pl.2) is probably about $1 \mathrm{mgd}$.

Water in the northwest buried-channel aquifer is relatively hard and has a high content of chloride, sulfate, and iron. According to Glen Berg, superintendent of Minot Water Treatment Plant, however, this water is easier (and therefore less expensive) to treat than water from other parts of Minot. 
The following list gives results of chemical analyses of water from four wells and a test hole tapping the aquifer. Analyses were made by the State Laboratories Department, Bismarck, N. Dak., and results are given in parts per million except where indicated.

Additional test drilling is required to determine the areal extent, thickness, and hydraulic characteristics of the northwest buriedchannel aquifer. The water is of marginal quality for many purposes. Wells in the aquifer produce as much as $1,000 \mathrm{gpm}$ and as littls as $15 \mathrm{gpm}$, indicating abrupt changes in thickness and grain size in the aquifer.

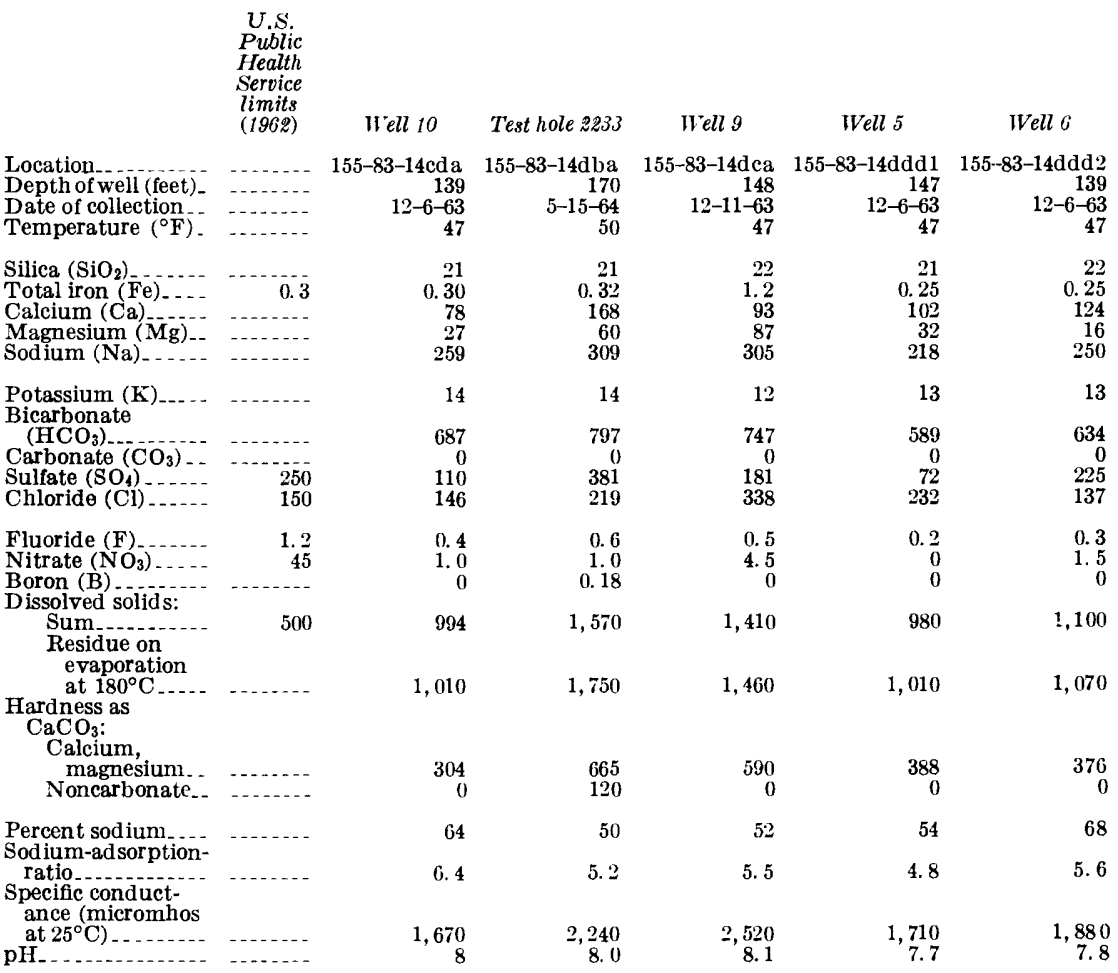

\section{MINOT AQUIFER}

The Minot aquifer consists of sand and gravel deposits of glaciofluvial origin. Of small areal extent, the aquifer occurs only in the Souris River valley and in the vicinity of Minot. Although only one test hole penetrated the entire thickness of the sand and gravel deposits in the central part of Minot, many test holes and wells have reached a probable basal boulder bed. The aquifer consists, in many places, of very coarse sandy gravel containing an abundance of boulders, but the size of the material may radically change within a 


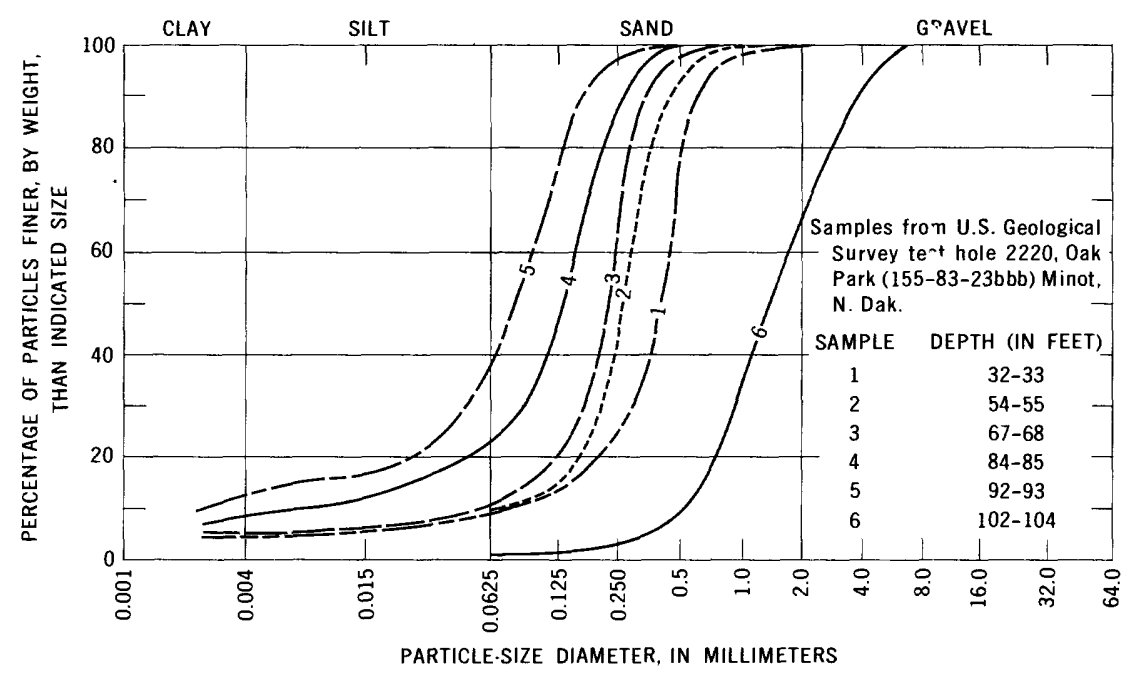

FIgURE 4.--Particle-size distribution of selected samples from the Minot aquifer at Oak Park in Minot.

few feet vertically or horizontally (fig. 4). It has a wide range in thickness, but commonly it is $30-50$ feet thick (pl. 1). In most places sand overlies the gravel; the sand may be as much as 85 feet thick. Where the sand is thick, the gravel is generally thin. In the westernmost part of Minot, near the Minot Sand and Gravel Co. pit, the coarse gravel is at land surface. In the eastern part of Minot, the gravel and sand are overlain by more than 80 feet of clay.

Origin of the Minot aquifer is difficult to determine. The sand and gravel forming the Minot aquifer was apparently deposited during several minor advances and retreats of glacial ice. At least part of the aquifer is related to the terrace deposits at the west end of Minot (pl. 1). The sediments in the central part of Minot may be related, in part, to the northwest buried-channel that was penetrated in test holes 2218 and 2233 ( $p l .2$ ), but the presence of clay layers that separate some of the sand and gravel layers is more difficult to explain.

The geology of the Minot aquifer is shown on a serios of three lithofacies grain-size-ratio maps (pl. 3). These maps represent, respectively, the depth intervals $0-50$ feet, 50-100 feet, and 100-150 feet below land surface. The maps are useful in determiniro areas of natural recharge from either surface or subsurface sources, in estimating isotransmissibility zones, in providing some indication of aquifer storage, in indicating aquifer boundaries, and (if sufficient data are available) in estimating the quantity of water in storage. 
The surface of the Minot aquifer slopes gently eastward, and wells at the west end of the city are shallower than those in the central and eastern parts.

\section{GROUND-WATER MOVEMENT}

The configuration of the contours on plate 3 indicates that water is moving into the ground-water depression in the Minot area from all directions. However, test drilling indicates that the west boundary of the Minot aquifer is near city well 18 (pl. 1), and that relatively impermeable glacial till forms the south walls of the valley. Consequently, probably only a relatively small amount of ground water moves from these directions.

In sections 14 and 15, T. 155 N., R. 83 W., however, the north wall of the valley consists predominantly of a sandy kame terrace, and ground water may move from it to the aquifer. Also, the northwest buried-chammel aquifer (pl. 2) consists, in places, of saturated sand and gravel more than 100 feet thick. Water from this aquifer moves southeastward toward the Minot aquifer near city wells 5, 6, 9, and 10. An estimated $1 \mathrm{mgd}$ flows from the northwest buried-channel ₹xuifer into the Minot aquifer.

\section{FLUCTUATIONS OF WATER LEVELS}

The Minot aquifer continually looses water by discharge and receives water by recharge. Consequently, the water level does not remain stationary but rises and falls with changes in storage. The changes in water level in the Minot aquifer are much the same as those in a surface reservoir; that is, the water level rises when recharge exceeds discharge and declines when the discharge is greater than the recharge. Thus, changes in the water levels in wells indicate a balance botween discharge and recharge. However, before conclusions can be reached about balance of recharge and discharge, the nature and cause of the water-level fluctuations must be examined, for a rise in the water level-as reflected in the records of the water levels in wells-is not in itself proof that water has been added to the aquifer. Eartl tides, earthquakes, loading on the aquifer, or a change in barometris pressure will cause the water level to fluctuate, but these factors relate to certain hydrologic characteristics of the aquifer and, hence, have no direct effect on the recharge-discharge balance. The net changes in water levels over a long period of time are the most significant in relation to the long-term balance between recharge and discharge.

The approximate position of the piezometric surface in the Minot aquifer in March 1946, based largely on water levels recorded in drillers' logs, is shown on plate 3 . 
The net decline of water level between March 1946 and I Larch 1964 is shown by contours on plate 3. During this period the greatest decline was in the western part of the aquifer, where eight municipal wells were installed in 1961 . The increased withdrawal of water from the western part of the aquifer and the decreased withdrawal from the eastern part accounts for the large differential decline in water levels in the aquifer.

Periodic measurement of the water levels in wells in the Minot area began in 1944 . The period of water-level measurements on city well 2 extends over 14 years, from 1944-59 (fig. 5). In 1959, measurements of the water level in city well 2 were discontinued. To supplement the records, water-level measurements in city well 8 for the per' $x$ 1963-64 were used. Well 8 is only 300 feet from well 2 , and their lithologic logs are similar. In general, the hydrograph of well 2 indicates that the water level declined less than 1 foot per year from 1944 to 1952 , rose about 5 feet per year from 1952 to 1955 , and declinod about 5 feet per year from 1956 to 1964 . A series of hydrographs representing a shorter period of water-level record in wells 5,6 , and 8-18 is shown in figure 6. Water levels declined rapidly at the close of 1961 after the completion of, and subsequent heavy pumping fron, city wells 11-18. The general decline continued into the early winter of 1963. A general trend toward equilibrium is indicated on the hydrographs from the early winter of 1963 through the fall of 1964 . T is trend is probably the result of decreased pumping during the fall and winter and of the large municipal withdrawals directly from the Souris River during the summer of 1964 .

Wells 5 and 6 are in the deeper, eastern part of the Minot aquifer. Even though these wells have been heavily pumped for nearly 20 years, the water levels have declined less than in wells in the wastern part of the city. This lesser decline is probably because of the proximity of the wells to large sources of natural recharge-namely, the northwest buried-channel and the lower Souris aquifers.

\section{ARTESTAN AND WATER-TABLE CONDITIONS}

Ground water occurs under both water-table and artesian conditions in the Minot aquifer. Water-table conditions exist in areas where the upper confining bed is missing and in areas where the water level has lowered below the bottom of the confining bed. Artesian conditions exist in areas where the water is under sufficient pressure to rise, in wells, above the bottom of the confining bed. Figure $r$ shows the areas of water-table and artesian conditions in the Minot aquifer in March 1964.

The water-level profile on plate 1 indicates that the areas of watertable and artesian conditions vary with the water-level f'uctuations 
in the aquifer. For example, a rise in water level will decresse the size of the water-table areas and increase the size of the artesian area; a lowering of the water level will result in the converse effect.

\section{RECHARGE}

\section{NATURAL RECHARGE}

Recharge is a process by which water is added to the zone of saturation; it may be either natural or artificial. In the Minot aquifer, natural recharge takes place by (1) direct infiltration of precipitation, (2) inflow of water from bedrock and glacial drift, and (3) infiltration from the Souris River. Figure 8 shows the areas and types of natural recharge to the Minot aquifer.

Direct infiltration of precipitation probably accounts for only a small amount of recharge to the Minot aquifer. The greatest arnounts probably occur in river-terrace and kame-terrace deposits and in the northwestern part of Minot (pl. 3, fig. 8).

The amount of recharge that can be attributed to inflow of water from the bedrock is at present, difficult to determine. Chemicrl analyses of water from the Minot aquifer suggest that recharge from the bedrock is minor, except in the westernmost part of Minot near city well 18. Recharge of bedrock water has probably increased concomitant, with the decline in water level in the Minot aquifer, but the quantity apparently has not been sufficient to make noticeable chan ges in the quality of the water.

The northwest buried-channel (pl. 2) and lower Souris aquifers probably supply the largest amount of recharge to the Minot aquifer. Estimates based on water-level gradients and drill-hole data suggest that recharge from these sources may be more than $2 \mathrm{mgd}$. Also, a considerable amount of natural recharge is derived from the Souris River. Figure 5 shows the relation between precipitation, discharge of the Souris River, and water level in the central part of the Minot aquifer. The data, which are from a 19-year period of record, indicate a direct relation between the discharge of the Souris River and the water level in the aquifer. In periods of drought, when the Souris River discharge is low, the water level declines; in periods of wet weather, when the river discharge is high, the water level rises. This relation was particularly evident in 1955 and 1956.

The Oak Park area, in the west-central part of Minot, and the area in the northwestern part of Minot are underlain predominantly by sand that permits rapid downward infiltration of river water and precipitation; hence, recharge from the Souris River is great in these areas (pl. 3, fig. 8). 
26 GEOHYDROLOGY, SOURIS RIVER VALLEY, MINOT, N. DAK.

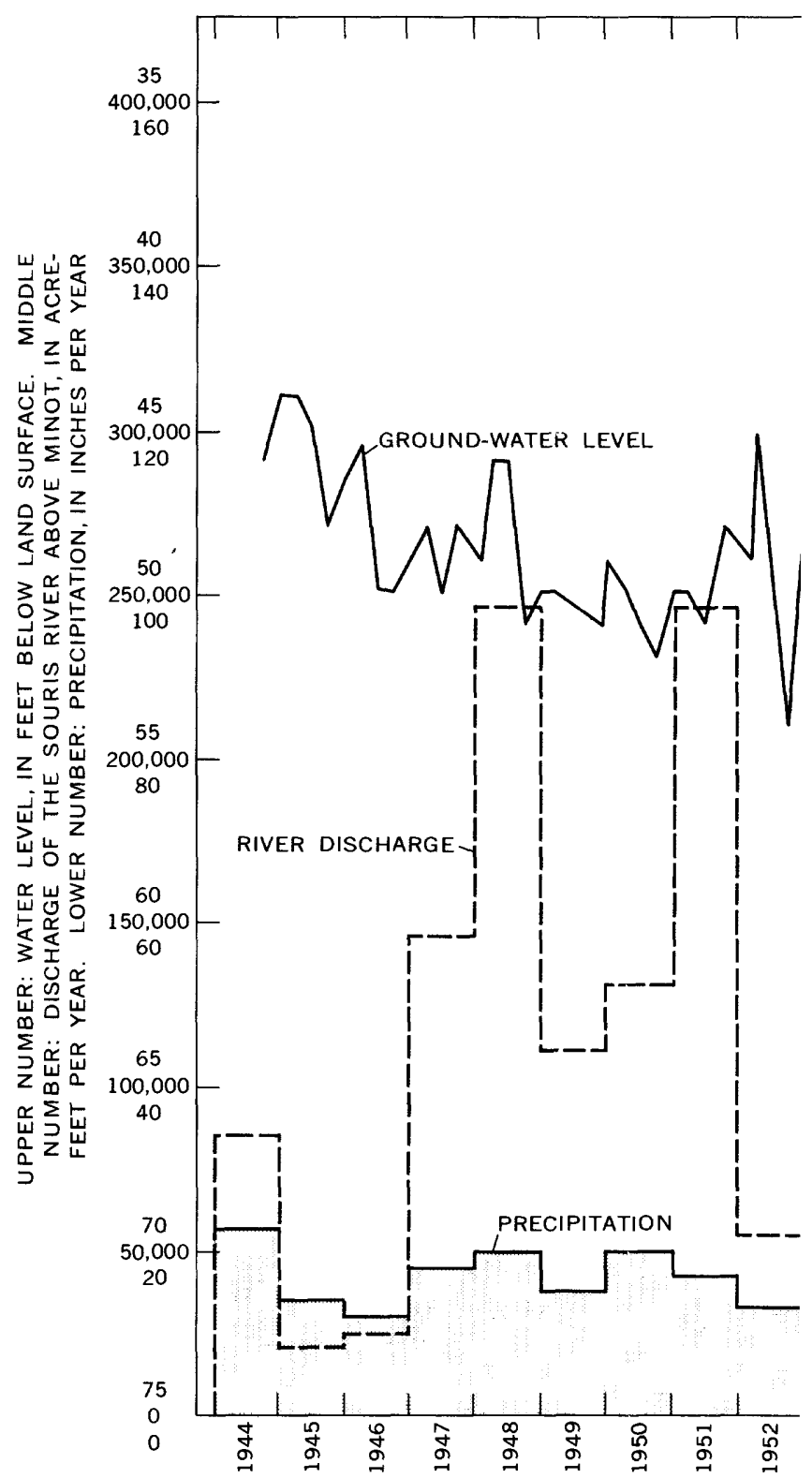

Figure 5.-Relation between precipitation, Souris River discharge for 1959 measured at Minot Experiment 


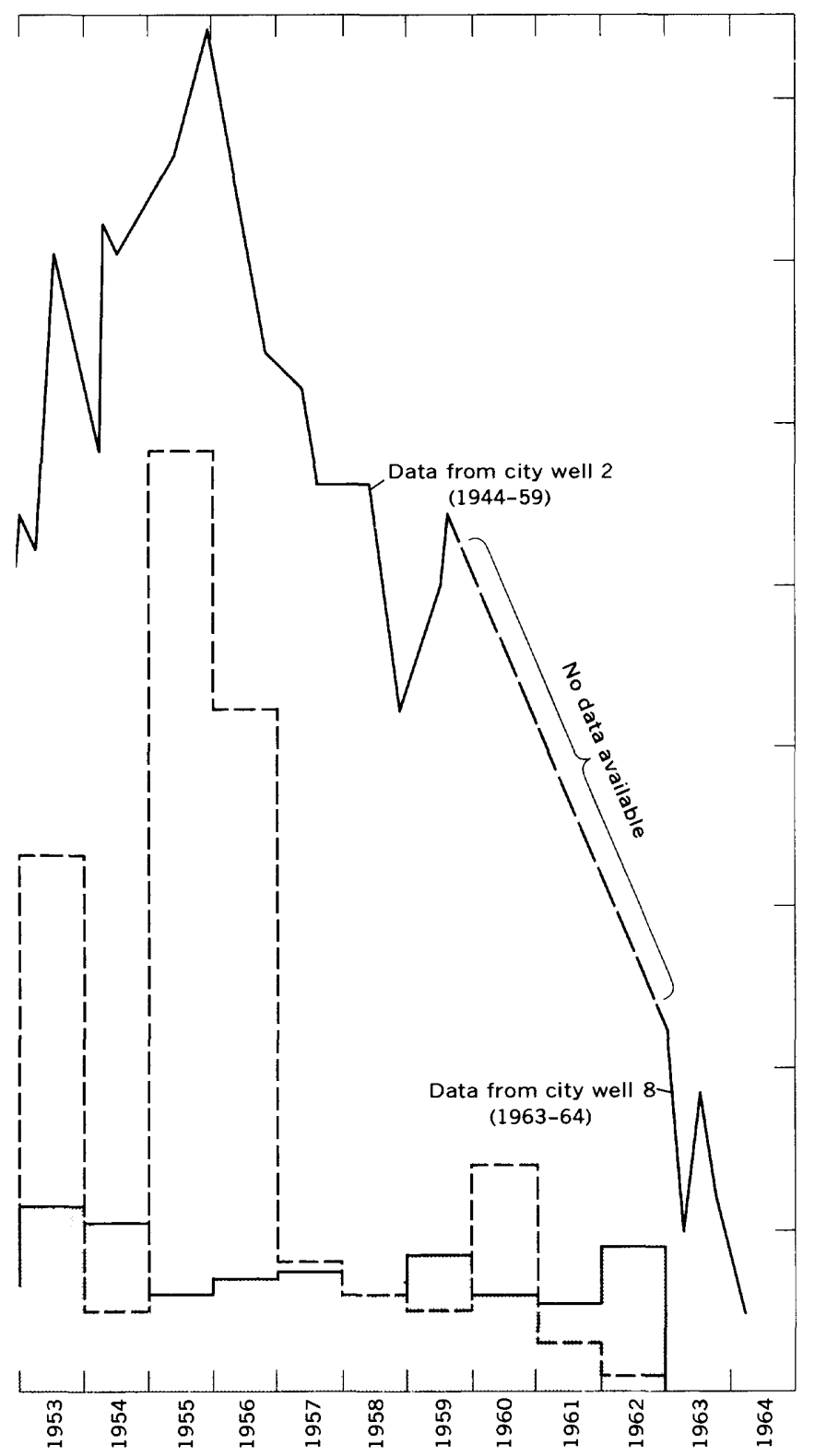

a. I water level in the central part of the Minot aquifer. Precipitation y'ation; others measured at Minot Airport. 


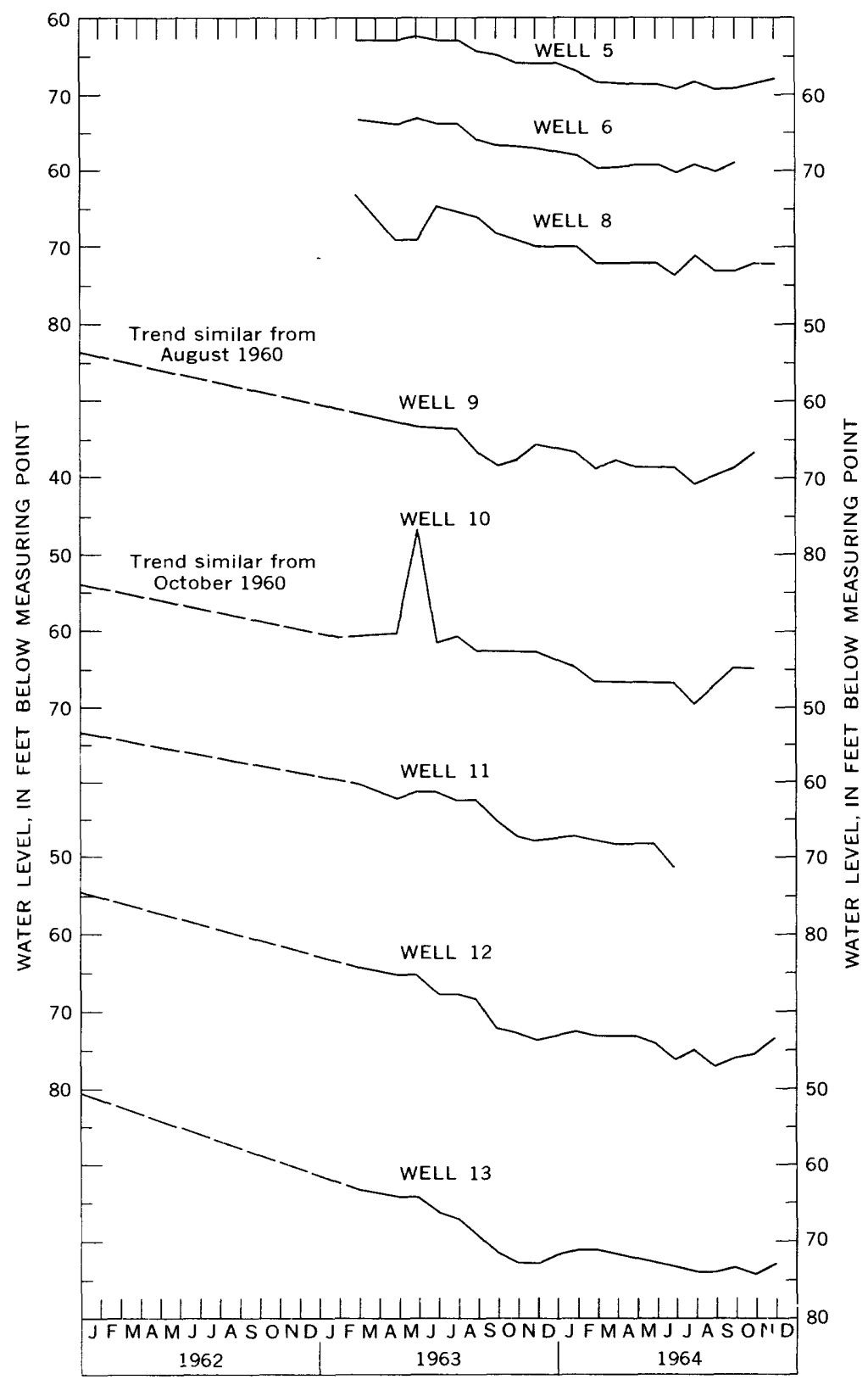

FIGURE 6.-Water-lerel fluctuation of Minot municipal well`. 


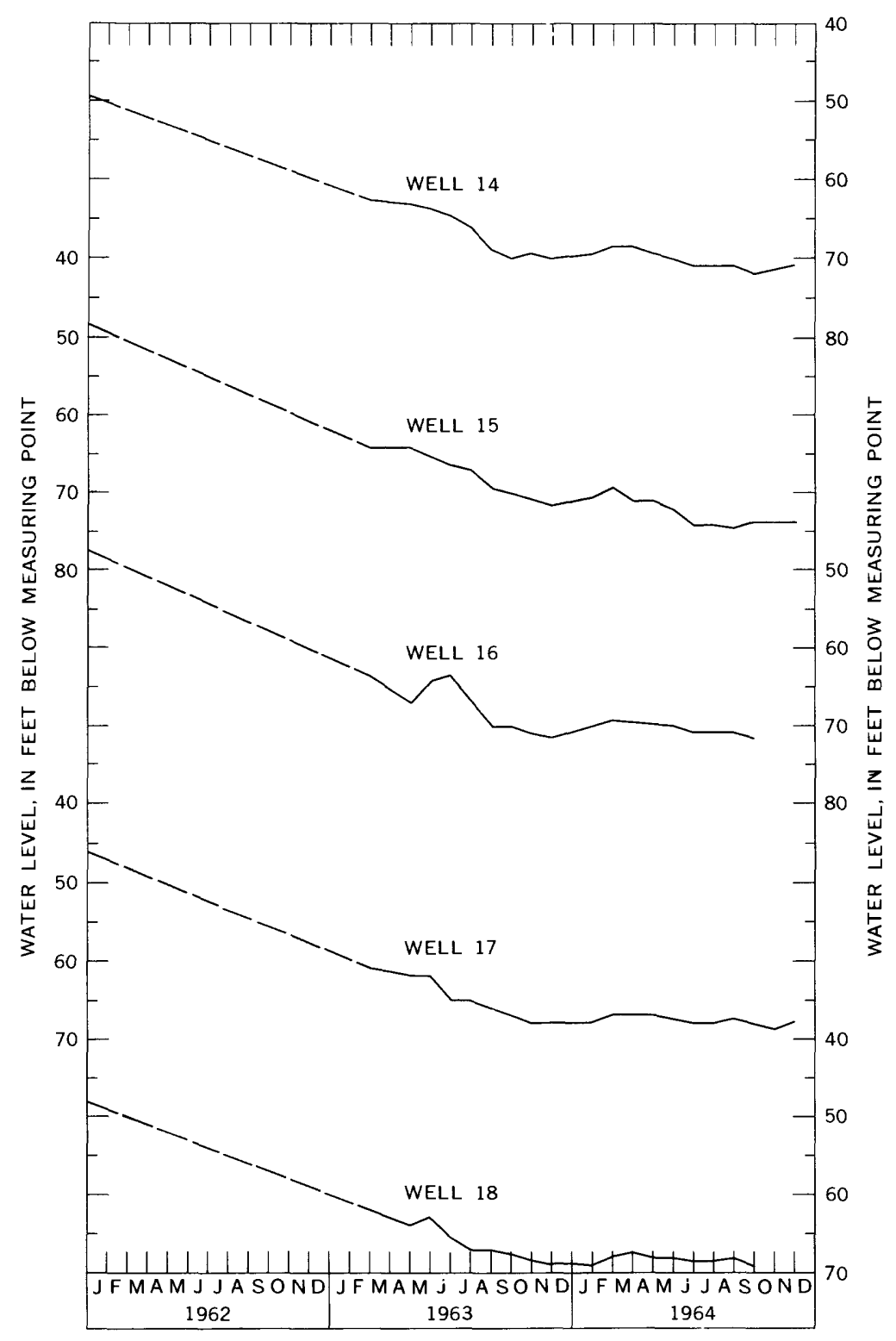

Figure 6.-Continued 


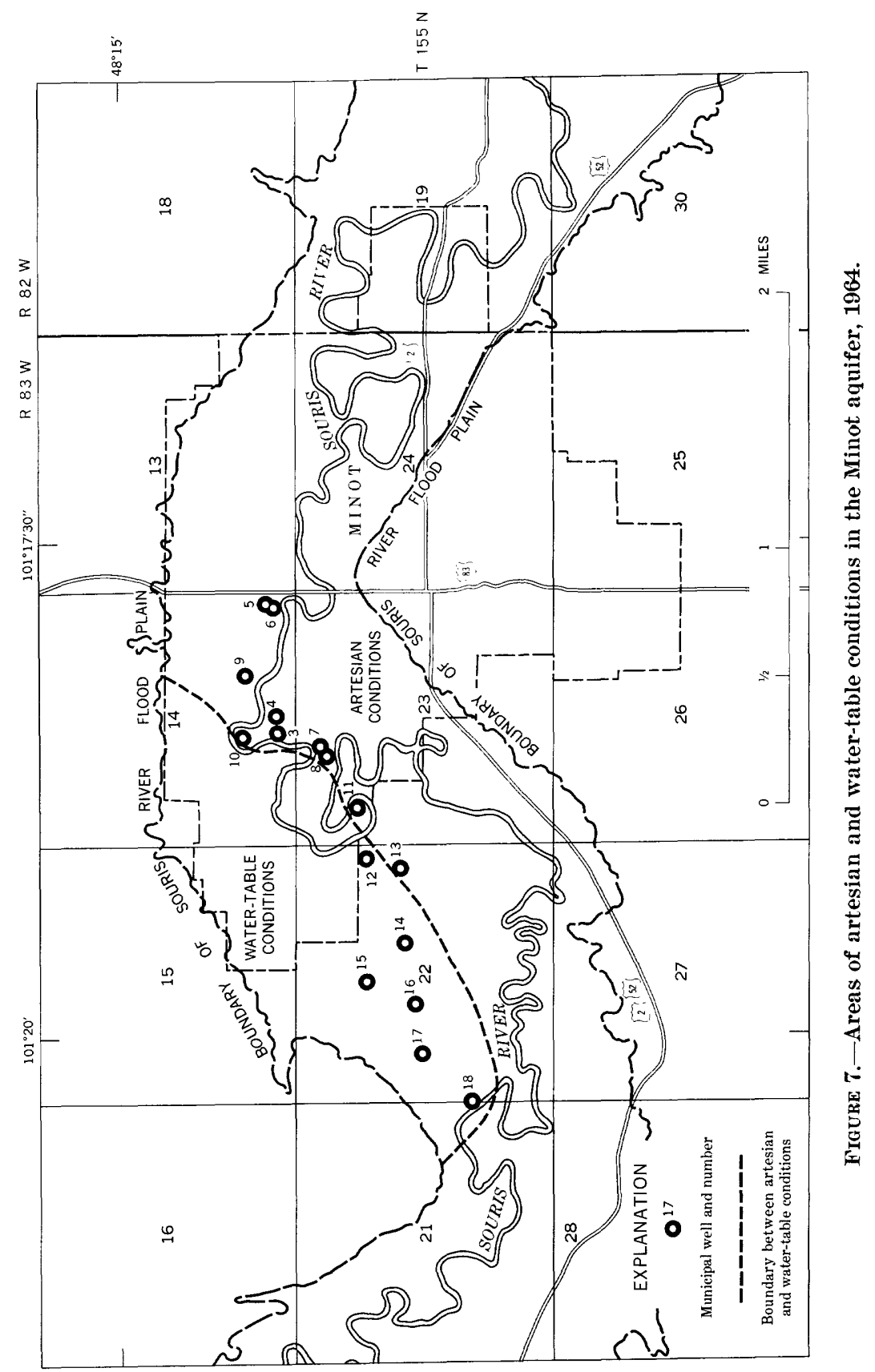


The flow of the Souris River was measured at eight sites ketween the Foxholm gaging station and Velva during releases from Lake Darling in September 1959. Some of these data were given by Bradley $(1963$, p. 8). The results are as follows:

Location

Flow,
in
cubic
feet
per
second

Souris River near Foxholm (measured 3 miles below U.S. Geol. Survey gaging station)

20.9

Souris River at Burlington (measured half a mile above the Des Lacs River)

Souris River at Minot Country Club (measured on crest of country club dam)

Souris River above Minot (measured a quarter of a mile below U.S. Geol. Survey gage)

Souris River at east Minot (measured half a mile below park dam)

Souris River at Logan (measured 1 mile northwest of Logan, about 8 miles southeast of Minot)

Souris River at Sawyer (measured a quarter of a mile north of Sawyer, about 15 miles southeast of Minot)

Souris River at Velva (measured 100 yards downstream from highwgy bridge, about 25 miles southeast of Minot)

The loss of flow between the Minot Country Club and the east Minot gaging station is $8.4 \mathrm{cfs}$ (cubic feet per second), or about $5.4 \mathrm{mgd}$. Bradley (1963) suggested that heavy pumping in the Minot well field was probably responsible for the loss, and that the increase in flow between the east Minot and the Logan station was the result of added effluent from the Minot sewage-treatment plant upstream. Although the area between the Minot Country Club and east Minot gaging station is an area of surface-water loss, Bradley's estimates may have been too high.

Surface water losses can be accounted for by at least two means other than direct recharge in the Minot area. First, in 1959 many of the sewers that extend under the river leaked, and probably much of the water lost by the river drained into these sewers through loose or broken joints. Second, some of the water lost could have gone into storage in the shallow perched aquifer in the western part of Minot. This aquifer is about 20 feet thick and is separated from the Minot aquifer by about 10 feet of clay. The permeability of the shallow aquifer is high and permits rapid lateral movement of water, but the underlying clay greatly reduced downward movement. Consequently, during above-normal river stages, water drains into the shallow squifer, where it is held in bank storage until a lowering of the river stage permits this water to drain back into the river. 


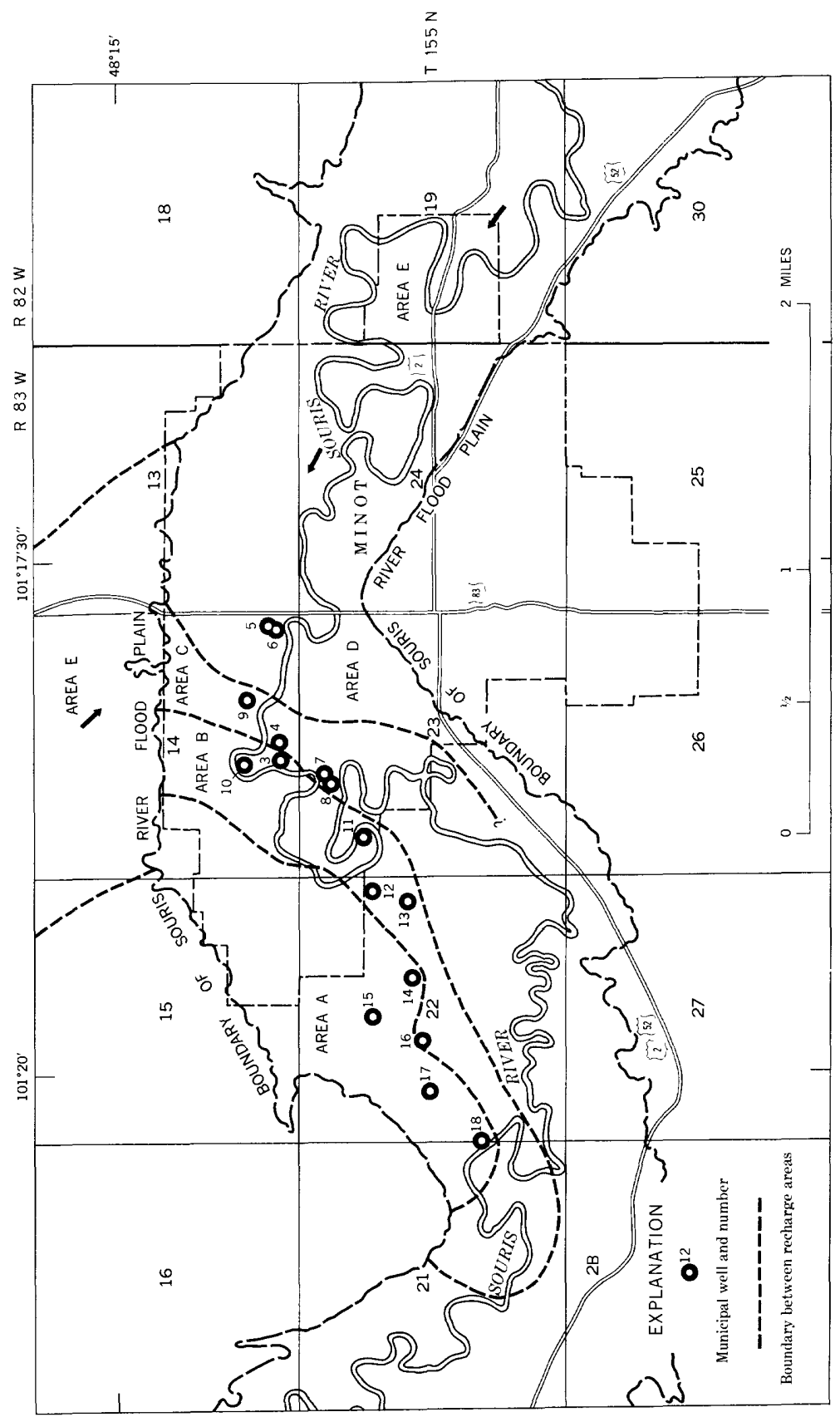

क क षै

Ð

母言

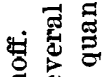

表茫

范密

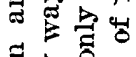

茟定定

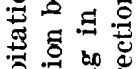

范些

논

峞苛

岁寻品

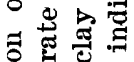

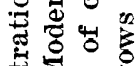

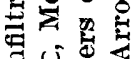

$\exists$ ט

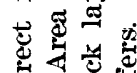

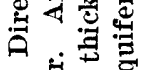

<蔗定

ฆ

帘帘

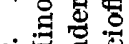

远苛

龸昰

요용

है

茟

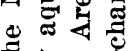

I.

욣 离

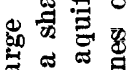

可

它宁

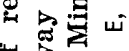

प्山े

经害曹

혀용

广号贺

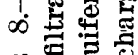

올 를 总 
Prior to development of the Minot aquifer, the piezometric surface in the aquifer was higher than the water table in the shallow aquifer. Under these conditions, water probably leaked from the Minot a auifer through the overlying aquiclude and into the shallow aquifer. Moreover, the author infers that the water level in the shallow aquifer was higher than that of the Souris River-except during high river stages-and that movement of the ground water was from the shallow aquifer into the river.

By the mid-1930's the withdrawal of ground water from the Minot aquifer had lowered the piezometric surface below the water table in the shallow aquifer, thereby causing downward leakage of water from the shallow aquifer to the Minot aquifer.

An average rate of recharge from the Souris River to the Minot aquifer is impossible to determine because of the wide extremes in change in river discharge and channel characteristics. Indirest evidence, however, suggests that during 1963-64 the Souris River probably supplied an average of about $500,000 \mathrm{gpd}$ of recharge, directly or indirectly, to the Minot aquifer. The greatest quantity of recharize generally takes place during flood conditions.

In summary, it appears that natural recharge to the Minot aquifer is approximately $3 \mathrm{mgd}$, of which about $2 \mathrm{mgd}$ is derived from buried glaciofluvial material, about $0.5 \mathrm{mgd}$ is influent seepage from the Souris River, and about $0.5 \mathrm{mgd}$ is received from bedrock sources, adjacent glacial till, and infiltration of precipitation.

\section{FEASIBILITY OF ARTIFICIAL RECHARGE}

Artificial recharge has been attempted at several locations in North Dakota; however, few data are available on the geology and hydrology of the recharge sites. One objective of this investigation was to determine the geology and hydrology of the area in order to allow selection of the most favorable sites for artificial recharge of the Minot aquifer.

At present (1964) the only sources of water available for artificialrecharge operations in the Minot area are the Souris River and its tributaries and the storage reservoirs on the Souris River, such as Lake Darling. Because flow of the Souris River varies from year to year (fig. 3), artificial recharge to the Minot aquifer would be restricted to those periods when flow is adequate in the river or when water is released from upstream reservoirs, unless impounding structures are constructed in Minot.

The lithofacies maps (pl. 3) indicate that a zone of clay overlies the Minot aquifer in the east half of the city but is absent in the northwestern part. The northwestern part of Minot therefore would be the more favorable area for artificial recharge. 


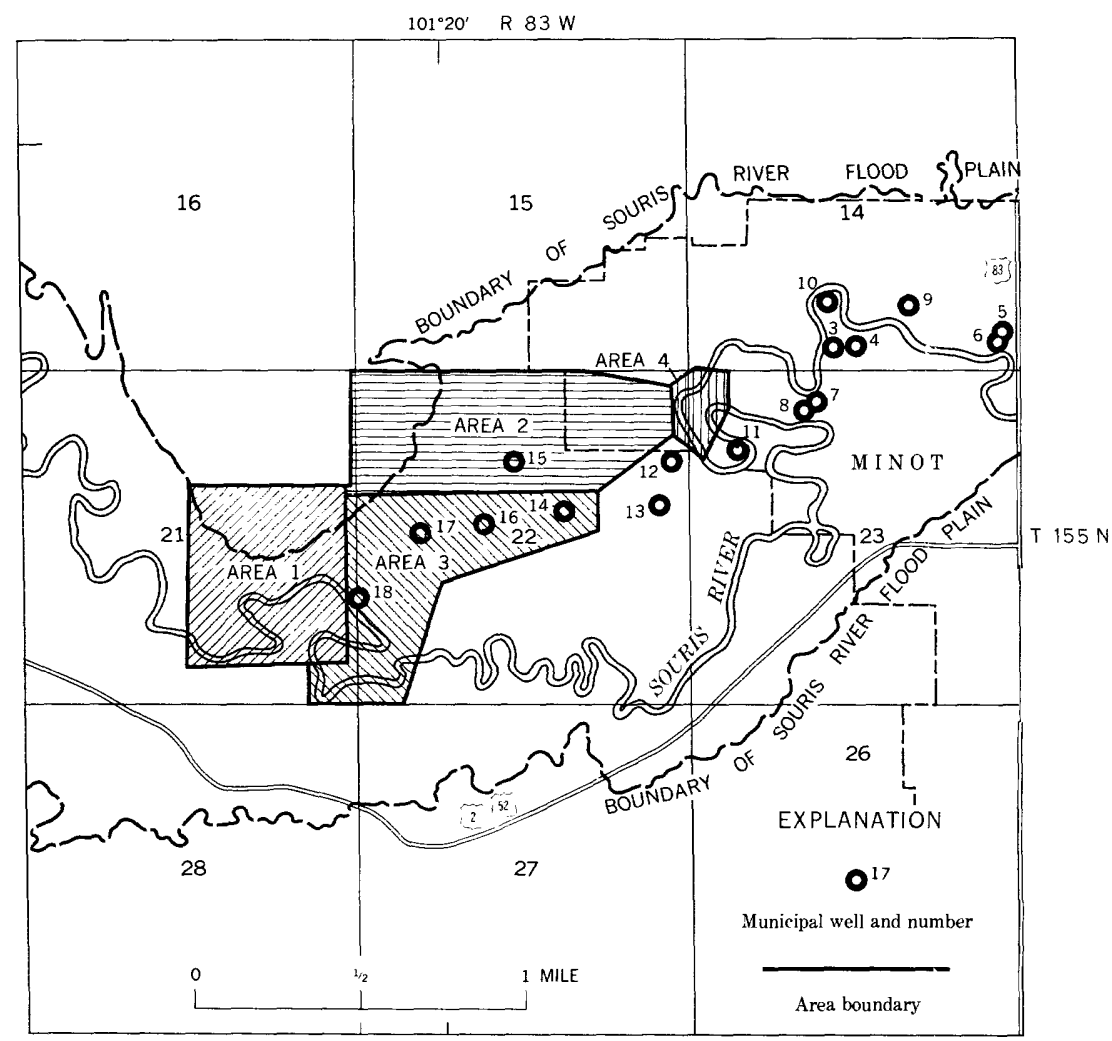

Figure 9.-Potential artificial-recharge sites in western Minot.

The exposure of sand and gravel in the Minot Sand and Gravel Co. pit at the west end of the city indicates that this may be a favorable site for artificial recharge (fig. 9, area 1). Tests should be made to determine the hydrologic continuity between the surface gravel and the gravel of the Minot aquifer. If continuity exists, th on the rate of river infiltration would possibly be increased by dredging the river near the gravel pit.

Several test holes and wells have been drilled in the nc rthern part of sec. 22, T. 155 N., R. 83 E. (Pettyjohn and Hills, 1965). Most of the test holes were drilled by a hydraulic rotary-drill rig. During the drilling, circulation was commonly lost at shallow depths; some of the holes were abandoned at depths of less than 30 feet because of the loss of circulation and because of extremely difficult drilling conditions. The drilling conditions were particularly poor in the flood plain adjacent to the river terrace (fig. 9). Lost drillirg-mud circulation in this area was caused by the highly permeablo sand and gravel at, or near, the land surface. The few test holes and wells 
completed in this area showed that the surface sand and gravel was directly connected with the Minot aquifer. The permeability of the sand and gravel penetrated by city well 15 is about 4,700 meinzer units (fig. 9) and artificial recharge facilities could be constructed in this area (fig. 9, area 2).

Artificial recharge sites would probably operate effectively in the area near wells 14 and 16-18 (fig. 9, area 3). The calculated permeability of the sand and gravel penetrated by wells $14,16,17$, and 18 is exceptionally high, as follows:

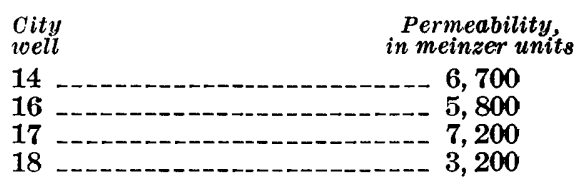

Logs of wells show that the aquifer in this area is only a few feet below land.surface. The high permeability of this part of the Minot aquifer would permit rapid spreading of water injected into the subsurface. Artificial recharge in this area would be greater because the drawdown from pumping the city wells would aid in the dissipation of a ground-water mound built up under a recharge pit. Also, the Souris River flows adjacent to this area, and dredging it would probably increase influent seepage to the Minot aquifer.

In the western part of the Oak Park area, fine- to medium-grained sand extends from land surface to a depth of about 100 feet, where it grades into gravel. The permeability of the sand is approximately 1,000 meinzer units, or three to seven times less than the permenbility in the same aquifer farther west. The permeability of the deeper sand and gravel is about 2,700 meinzer units in well 11, 2,200 in well 12 , and 2,100 in well 13. The western part of the Oak Park area offers opportunities for artificial-recharge basins because of the apparent lack of impermeable strata throughout the glaciofluvial material (fig. 9, area 4). In addition, the Souris River flows through, or near, the most favorable sites. This part of the Oak Park area is probably a zone of considerable influent seepage, and one in which the seepage could probably be increased by dredging.

Several major advantages would result from artificial recherge of the Minot aquifer:

1. The major water-level declines would be diminished or stopped.

2. The resulting higher water levels would reduce pumping lifts anc. hence, pumping costs.

3. The quality of the water in the western part of the aquifer would be improved by reducing the inflow of poor-quality water from the bedrock aquifers.

4. The chemical quality of the induced river water, in particular the bacteria content, would be improved by natural flltration. 
5. Water-treatment costs would be reduced.

6. Excess river water would be stored underground, thus aroiding waste.

7. Well interference would be reduced.

8. Withdrawal rates could be increased.

9. Well-screen oxidation and corrosion would be reduced.

A report on the artificial-recharge experiments in the Minot area is in progress.

\section{DISCHARGE}

Ground water is discharged by evapotranspiration, as seepage to streams or lakes, as underflow to adjacent areas, and as pumpage from wells. Pumpage from municipal wells is the largest withdrawal of water from the Minot aquifer.

EVAPOTRANSPIRATION, SEEPAGE TO STREAMS, AND UNDEFFLOW

Water losses by evapotranspiration are large where the water level is near the land surface, especially during the summer groving season. The water level in most of the Minot aquifer is more than 65 feet below land surface (fig. 4) and evapotranspiration from it is slight. In contrast, the shallow aquifers, such as those in the western part of Minot and beneath the adjacent uplands, may discharge large quantities of water by evapotranspiration.

The Minot aquifer probably does not discharge ground water to streams under present hydrologic conditions. The shallow aquifer in the western part of Minot releases water from riverbank storage to the Souris River and its tributaries during low flow stages of the river.

The piezometric map representing the water-level conditions in 1964 (pl. 3) indicates that underflow occurs only into the Minot aquiier. The map also indicates that underflow out of the Minot area is negligible under the present hydrologic conditions.

\section{PUMPAGE FROM WELLS}

The history of ground-water development in the Minot area has been discussed by Simpson (1929) and by Akin (1947). The city has 16 municipal wells; of these, 13 are being used. Annual pumpage from municipal wells during 1944-63 is shown in figure 10. The annual pumpage has more than tripled since 1944. In contrast, pumpage from industrial wells in 1964 may be less than in 1944, but pumpage records are incomplete. Exceptionally heavy withdrawals from the Minot aquifer in 1961-63 were a result of (1) drought, (2) decrease and eventual termination of pumping directly from the Souris River, (3) increased population, and (4) water-supply needs of the Minot Air Force Base.

In general, the largest pumpage from the well field is during JuneAugust (fig. 11). During this period in 1963 the averace pumpage from municipal wells was nearly $5 \mathrm{mgd}$, but it was more than $7 \mathrm{mgd}$ 


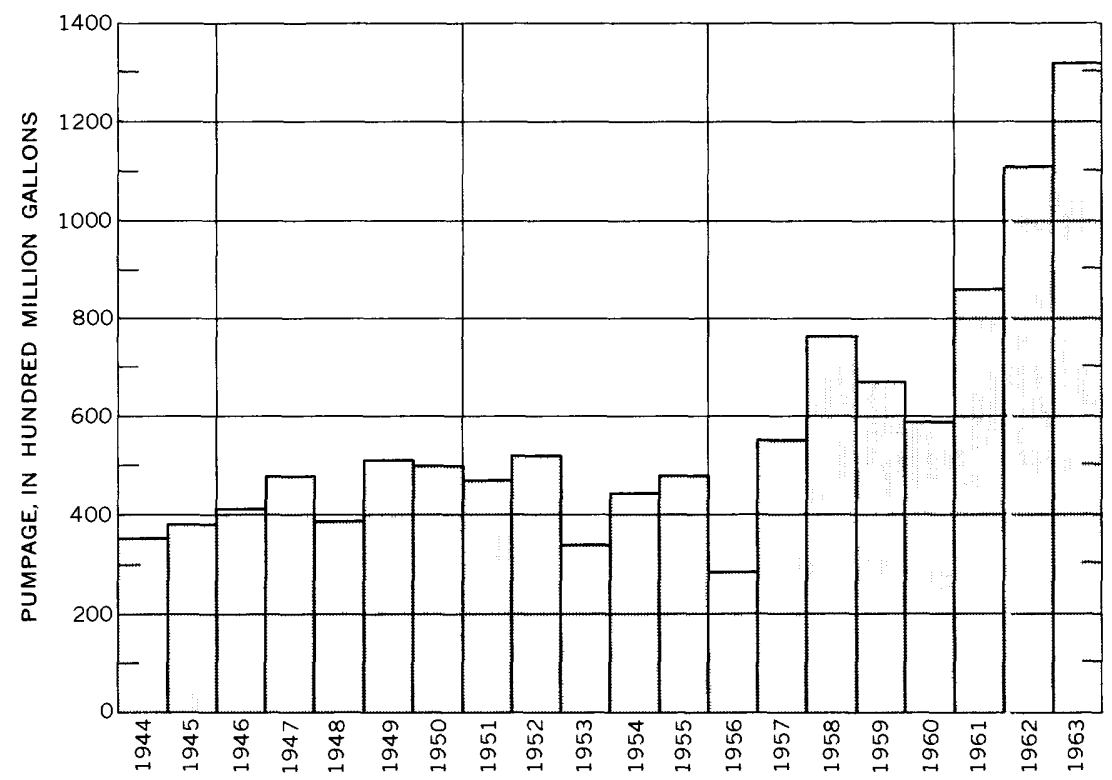

FigURE 10.--Annual pumpage of Minot municipal wells, 1944-63.

during short intervals. The least amount of pumpage is during January-March; in 1964 pumpage averaged about $3.3 \mathrm{mgd}$ for this period.

Municipal pumping from the Souris River was begun on May 28 . 1964 , and was continued throughout the rest of that year. Municipal pumpage from wells was decreased during the period of river withdrawal. A comparison of average rates of pumpage, in million gallons per day, during the summers (June-August) of 1963 ard 1964 is as follows:

\begin{tabular}{|c|c|c|c|c|c|c|}
\hline \multirow[b]{2}{*}{ Source } & \multicolumn{2}{|c|}{ June } & \multicolumn{2}{|c|}{ July } & \multicolumn{2}{|c|}{ Augus: } \\
\hline & 1963 & 1964 & 1963 & 1964 & 1963 & 18 \\
\hline Minot aquifer & 5.0 & 2.4 & 5.1 & 3.2 & 4.5 & 3 \\
\hline Souris River. & 0 & 1.7 & 0 & 2.3 & 0 & \\
\hline Total _. & 5.0 & 4.1 & 5.1 & 5.5 & 4.5 & 5.7 \\
\hline
\end{tabular}

A comparison of hydrographs for June-August 1963 and tha same period in 1964 (fig. 6) shows that the reduced withdrawals from the aquifer during 1964 had significant effects on the water-level decline. The average withdrawal from the aquifer by municipal wells during this period in 1963 averaged $4.8 \mathrm{mgd}$, and the average water-level decline for the period was 3.2 feet. The largest water-level decline, 6.5 feet, occurred in city well 16 ; the least decline, 1 foot, was in city well 10. During the same period in 1964, however, the average withdrawal was $3 \mathrm{mgd}$, and the average water-level decline was 0.1 foot. 


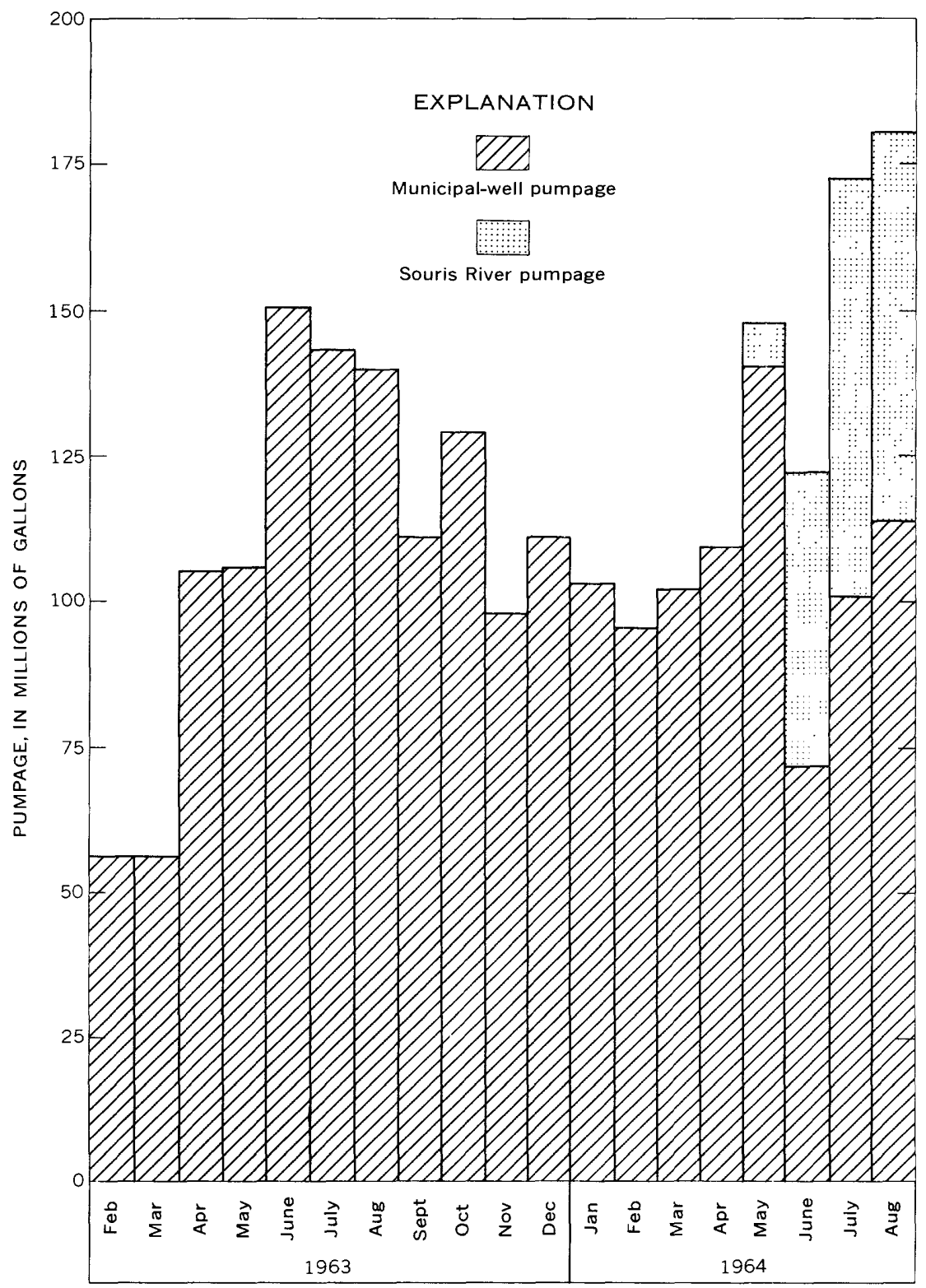

FIGURE 11.-Monthly pumpage from Minot municipal wells and from the Souris River, February 1963-August 1964. 
Wells 8,16 , and 18 declined an average of 0.5 foot, whereas well 10 recovered 2.5 feet.

The available data indicate that under the present conditions the Minot aquifer can supply only about $3.0 \mathrm{mgd}$ without a substantial decline of water level. However, increased infiltration from the river, a greater amount of pumpage directly from the river, and ar ificial recharge would allow larger withdrawals from the aquifer without seriously lowering the water level.

Figure 12 shows the distribution and magnitude of pumpage from 14 wells during 1963 . The variable characteristics of the Minot aquifer and the uneven pumpage distribution produce significant interference effects in places, particularly in the area of artesian conditons (fig. 7).

\section{AQUTFER HYDRAULICS}

COEFFICIENTS OF PERMEABILITY, TRANSMISSIBILITY, AND STORAGJ, AND SPECIFIC CAPACITY

Physical and hydrologic properties of selected samples from the Minot aquifer are given in table 1. The laboratory coefficients of permeability given in table 1 are considerably lower than data dorived from field studies. The apparent discrepancy is the result of many factors, but the major reason for it lies in the inability to collect representative samples of coarse gravel by means of rotary drilling. The high permeability of the Minot aquifer may be attributed largely to coarse gravel and boulders in the lower part of the aquifer, anc these were not adequately represented in the samples. Table 1 shows that marked differences in hydrologic properties may exist in a rock unit that appears to be homogenous. A small amount of clay or sijt may considerably reduce permeability. To illustrate this, compare table 1 with figure 4 .

TABLE 1.-Physical and hydrologic properties of samples from the Minot aquifer [Analyses by the U.S. Geol. Survey Hydrologic Lab., Denver, Colo.]

\begin{tabular}{|c|c|c|c|c|c|c|c|c|}
\hline Rock type 1: & $\underset{\text { (feet) }}{\text { Depth }}$ & $\begin{array}{c}\text { Specific } \\
\text { gravity } \\
\text { of } \\
\text { solids }\end{array}$ & $\begin{array}{l}\text { Dry } \\
\text { unit } \\
\text { weight } \\
\text { (g per } \\
\text { cc) }\end{array}$ & $\begin{array}{l}\text { Centrifuge } \\
\text { moisture } \\
\text { equivalent } \\
\text { (percent) }\end{array}$ & $\begin{array}{l}\text { Specific } \\
\text { retention } \\
\text { (percent) }\end{array}$ & $\begin{array}{c}\text { Total } \\
\text { porosity } \\
\text { (percent) }\end{array}$ & $\begin{array}{l}\text { Specific } \\
\text { yield } \\
\text { (percent) }\end{array}$ & $\begin{array}{l}\text { Cjefficient } \\
\text { of perme- } \\
\text { ability } \\
\text { (meinzer } \\
\text { units) }\end{array}$ \\
\hline Clay - - & $22-23$ & 2.73 & 1. 23 & 49. 4 & 47.0 & 54.9 & 7.9 & 0.003 \\
\hline Do $\ldots$ & $24-25$ & 2.72 & 1.24 & 42.8 & 44.0 & 54.4 & 10.4 & .008 \\
\hline Fine to coarse sand & $32-33$ & 2.71 & 1. 66 & 3.9 & 10.0 & 38.7 & 28.7 & 31.0 \\
\hline Do $\ldots \ldots$ & $54-55$ & 2.70 & 1. 60 & 3.8 & 9.5 & 40. 7 & 31.2 & 47. 0 \\
\hline Silty fine sand. & 57 & 2.68 & 1.45 & 20.5 & 29.1 & 45,9 & 16.8 & .08 \\
\hline Fine to coarse sand & $67-68$ & 2.70 & 1.57 & 4. 7 & 10. 7 & 41.9 & 31.2 & 18.0 \\
\hline Clayey fine to & & & & & & & & \\
\hline medium sand. & $84-85$ & 2.66 & 1.55 & 7.9 & 14.8 & 41.7 & 26.9 & .7 \\
\hline $\begin{array}{l}\text { Do } \\
\text { Gravelly fine to }\end{array}$ & $92-93$ & 2.67 & 14 & & & & 28.7 & 1. 0 \\
\hline very coarse sand... & $102-104$ & 2. 72 & 1. 79 & 1.2 & 4.8 & 34.2 & 29.4 & 970.0 \\
\hline
\end{tabular}

I All but the last sample are core samples; the last sample is a hydraulic rotary sample. See firure 4 for particle-size-distribution curves.

2 Samples were taken from test hole 2220, location 155-83-23bbb, Oak Park, Minot. 


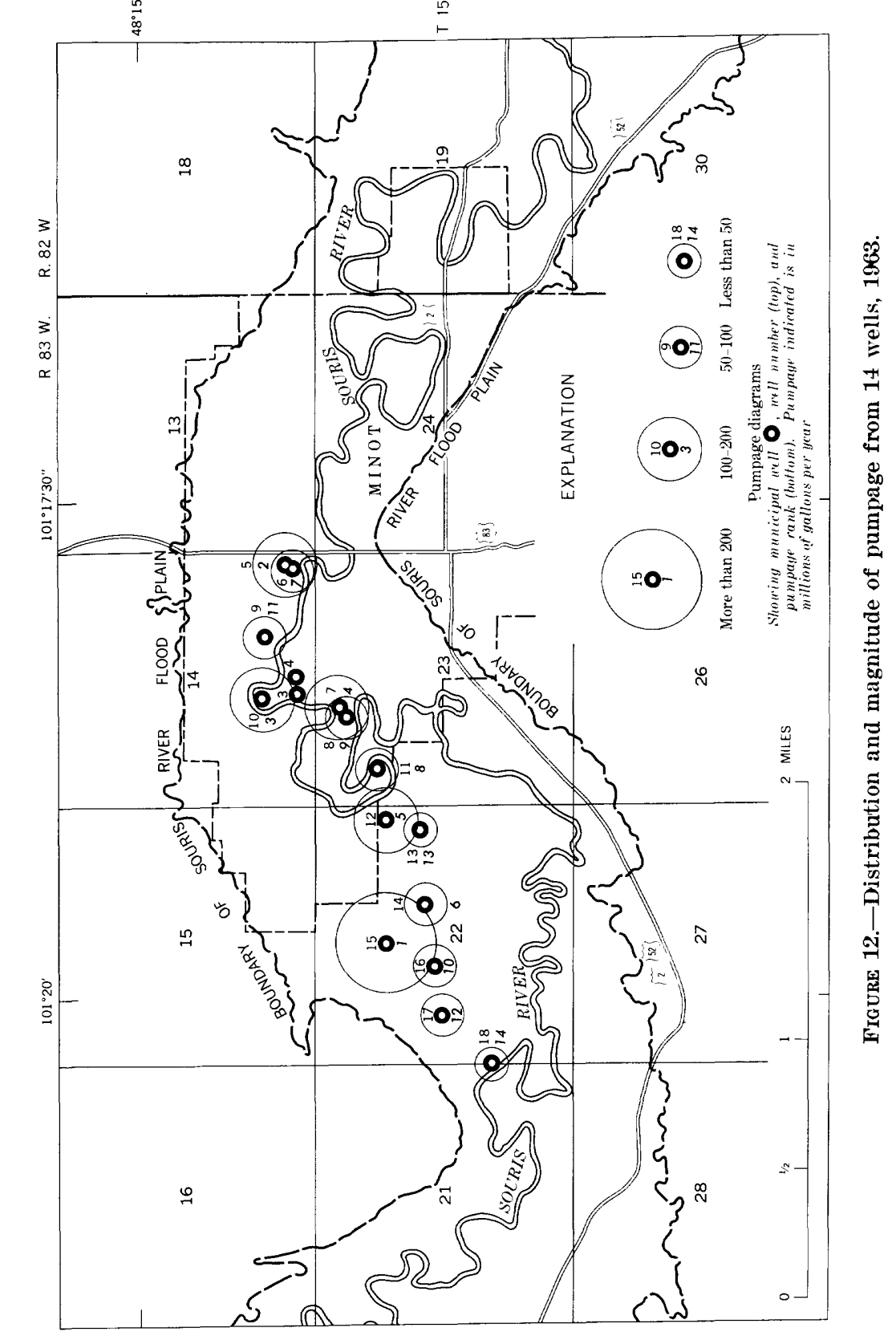


Transmissibilities of the Minot aquifer are given in table 2. The data from Akin (1947) are most accurately determined, but they do not reflect the conditions in 1964 because the water level has declined nearly 30 feet since 1946, when the tests were run. Transmissibilities determined by development- and production-test data are less accurate owing to short pumping periods ( $24 \mathrm{hrs}$ ), lack of accurate drawdown data, and inadequate well development; but they probably are reasonably correct.

The transmissibility in much of the Minot aquifer probably exceeds 250,000 gpd per $\mathrm{ft}$, which is higher than in any other areas in North Dakota known at this time.

TA BLE 2.-Transmissibility, in gallons per day per foot, of the Minot aquifer

\begin{tabular}{|c|c|c|c|c|c|c|}
\hline \multirow{3}{*}{$\frac{\text { Well }}{\text { City test well } 10}$} & \multirow{2}{*}{$\begin{array}{l}\text { From } \\
\text { A kin } \\
(1947)\end{array}$} & \multirow{2}{*}{$\begin{array}{l}\text { Deter- } \\
\text { mined in } \\
\text { this } \\
\text { study }\end{array}$} & \multicolumn{3}{|c|}{ Estimated 1} & \multirow{2}{*}{ Remarks } \\
\hline & & & 1964 & \multicolumn{2}{|c|}{$1946-61$} & \\
\hline & \multirow{4}{*}{$\begin{array}{l}259,000 \\
259,000 \\
259,000 \\
264,000 \\
163,000 \\
216,000\end{array}$} & & & & & \multirow{5}{*}{ Test hole $T-1$, adjacen $t$ to well 5} \\
\hline City well: & & & & & & \\
\hline & & & & & & \\
\hline 5 & & & 312,000 & $\begin{array}{r}42,000 \\
354,000 \\
300,000\end{array}$ & $\begin{array}{l}1940 \\
1958 \\
1946 \\
1946\end{array}$ & \\
\hline 6 & & & 350,000 & \multirow{3}{*}{$\begin{array}{r}270,000 \\
142,000 \\
94,000 \\
124,000 \\
76,000\end{array}$} & 1947 & \\
\hline 8 & & - & 312,000 & & 1948 & \multirow[b]{2}{*}{$\begin{array}{l}\text { Corroded screen in } 1964 \text {. } \\
\text { Several boundary conditions } \\
\text { noted. Corroded screen in } \\
1964 \text {. }\end{array}$} \\
\hline $10 \ldots$ & & 74,300 & 50,000 & & $\begin{array}{l}1960 \\
1960\end{array}$ & \\
\hline 11 & & 107,200 & 114,000 & 80,000 & 1961 & \multirow{3}{*}{$\begin{array}{l}\text { Leaky artesian condit'ons. } \\
\text { Several boundary ccnditions. } \\
\text { Multiple boundaries; water- } \\
\text { table or leaky artesian con- } \\
\text { ditions. } \\
\text { Do. }\end{array}$} \\
\hline $12 \ldots$ & & 151,000 & 240,000 & 178,000 & 1961 & \\
\hline 13. & & \multirow{3}{*}{$\begin{array}{l}81,000 ? \\
364,000 \\
294,000 \\
350,000 ?\end{array}$} & 114,000 & \multirow{3}{*}{$\begin{array}{r}50,000 \\
166,000 \\
400,000 \\
200,000\end{array}$} & 1961 & \\
\hline 15 & & & $\begin{array}{l}800,000 \\
400,000\end{array}$ & & $\begin{array}{l}1961 \\
1961\end{array}$ & \multirow{2}{*}{$\begin{array}{l}\text { Do. } \\
\text { Plot suggests two re } \\
\text { boundaries. }\end{array}$} \\
\hline 16 & & & 300,000 & & 1961 & \\
\hline $\begin{array}{l}17 \ldots \ldots \\
18 \ldots\end{array}$ & & $\begin{array}{l}254,000 \\
150,000 ?\end{array}$ & & $\begin{array}{l}228,000 \\
200,000\end{array}$ & $\begin{array}{l}1961 \\
1961\end{array}$ & \multirow{4}{*}{$\begin{array}{l}\text { Probably water-table conditions. } \\
\text { Several boundary conditions. } \\
\text { Artesian to water-table con- } \\
\text { ditions in } 1961 .\end{array}$} \\
\hline Bison generating & & \multirow{4}{*}{$\begin{array}{r}156,000 \\
5,000\end{array}$} & & & & \\
\hline $\begin{array}{l}\text { plant. } \\
\text { Minot Sta } \\
\text { lege well }\end{array}$ & & & & & & \\
\hline $\begin{array}{l}\text { lege well, } \\
\text { Minot Mill well }\end{array}$ & 225,000 & & & & & \\
\hline & & & & & & A quifer test in 1946. \\
\hline
\end{tabular}

1 Estimated by multiplying specific capacity by 2,000 .

The coefficients of storage from selected well data from the Minot aquifer are given in table 3 . Data are not available for determining the coefficient of storage in the western, or water-table, part of the aquifer. Limited information suggests, however, that the storage coefficient in this area is about 0.10 . 
Specific capacities of selected wells in the vicinity of Minot are given in table 4. The low specific capacities of wells $3,4,9$, and 10 probably reflect well-screen condition or other well-construstion problems. Transmissibility can be estimated by multiplying the well specific capacity by 2,000 , but the condition of the well is an influencing factor.

From drillers' logs, lengths of screens, and reported well depths, it appears that the Minot municipal wells only partly penetrate the aquifer. Consequently, the wells have more drawdown and interference than if they were fully penetrating. Because penetration is only partial, the cited values of transmissibility, storage, and specific capacity are lower than would be those of fully penetrating wells.

TABLE 3.-Coefficient of storage for the Minot aquifer at selected well sites

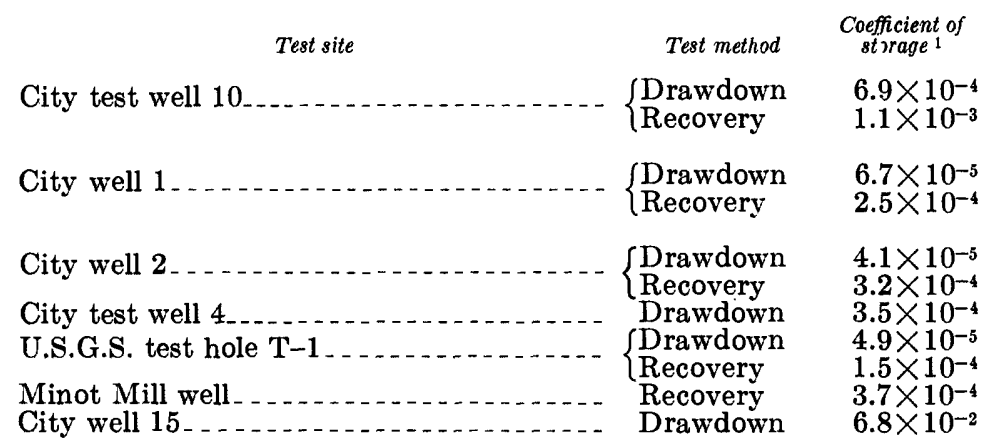

${ }^{1}$ Coefficient of storage data are from Akin (1947) except that for city well 15 , which is from a routine 24 -hour production test made in 1961 .

$\mathrm{T}_{\mathrm{ABLE}}$ 4.--Specific capacities, in gallons per minute per foot of drawdown, of selected wells in the vicinity of Minot

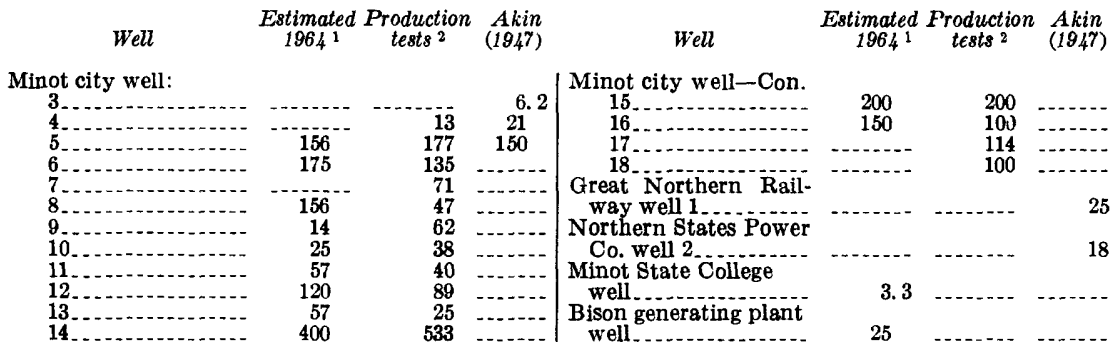

1 Data for Minot city wells estimated from airline gage under static conditions and after 13 hours pumping. Data for Minot State College well supplied by M. Williams. Data for Bison generating pl ant supplied by R. Ness.

2 Calculations from routine 24-hour-production pumping tests. Data supplied by the Mino ${ }^{+}$City Engineer. 


\section{INTERFERENCE AND DRAWDOWN}

During pumping of a well, the cone of depression expands, causing the water levels in adjacent wells to decline. When the cores of depression of two or more wells overlap, interference occurs, causing either a loss of yield or an increase in drawdown in each well. Generally the closer the wells, the greater the interference.

Several Minot wells are close together; in particular, wells 5 and 6 are about 200 feet apart, wells 7 and 8 are 300 feet apart, wells 12 and 13 , about 880 feet apart, and wells 14 and 16, about 930 feet apart. Wells $9,10,11,15$, and 17 are more than 1,100 feet from neighboring wells.

By determining the interference effects in a well field, a pumping program can be planned that will result in the least interference and, thus, in lower production costs. Pumped wells should be spaced as far apart as practical or else a network of many wells that have smaller discharge rates should be utilized.

Predicted drawdowns caused by pumping wells $5,7,8$, and 15 at a rate of $700 \mathrm{gpm}$ for selected periods are shown in figures 13 and 14. Wells 5, 7, and 8 tap the artesian part of the Minot aquifer; well 15 taps the water-table part of the aquifer. The plots were calculated from data obtained from aquifer tests in Minot in 1946 (Akin, 1947) and from production-test data for well 15 in 1961 . These data prob-

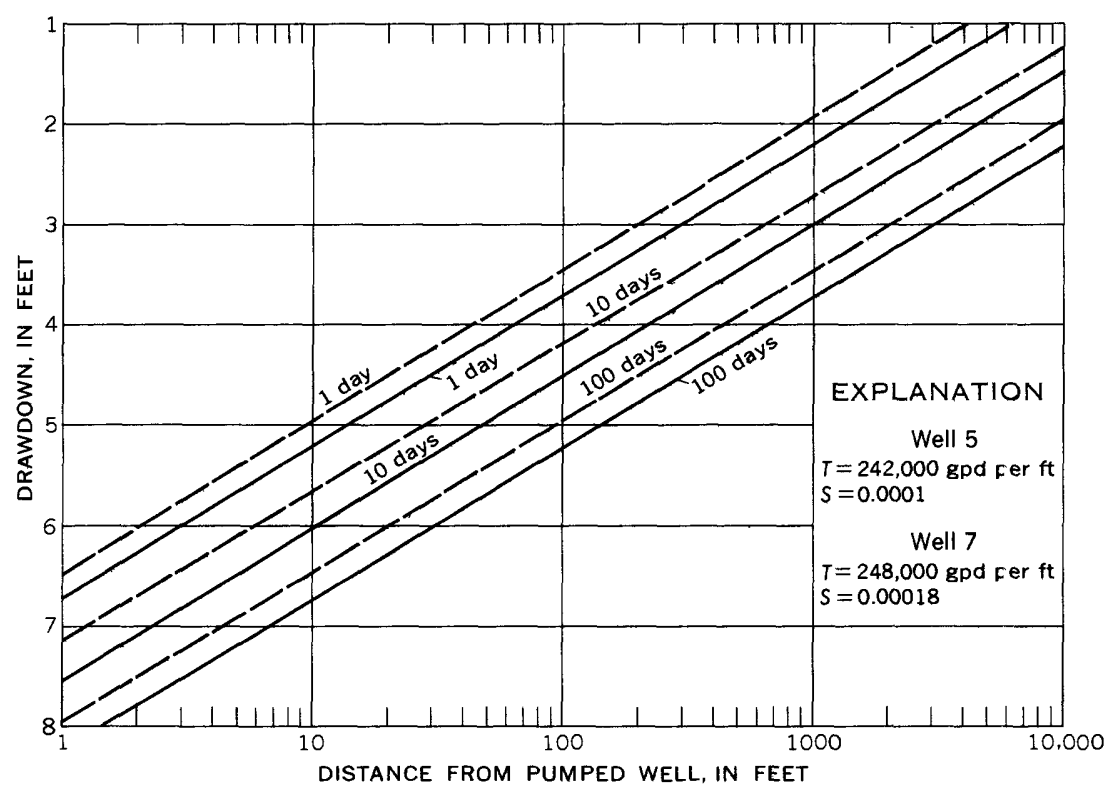

Figure 13.-Predicted drawdowns near city wells 5 (solid line) and 7 (dashed line), each discharging $700 \mathrm{gpm}$ for selected periods. 


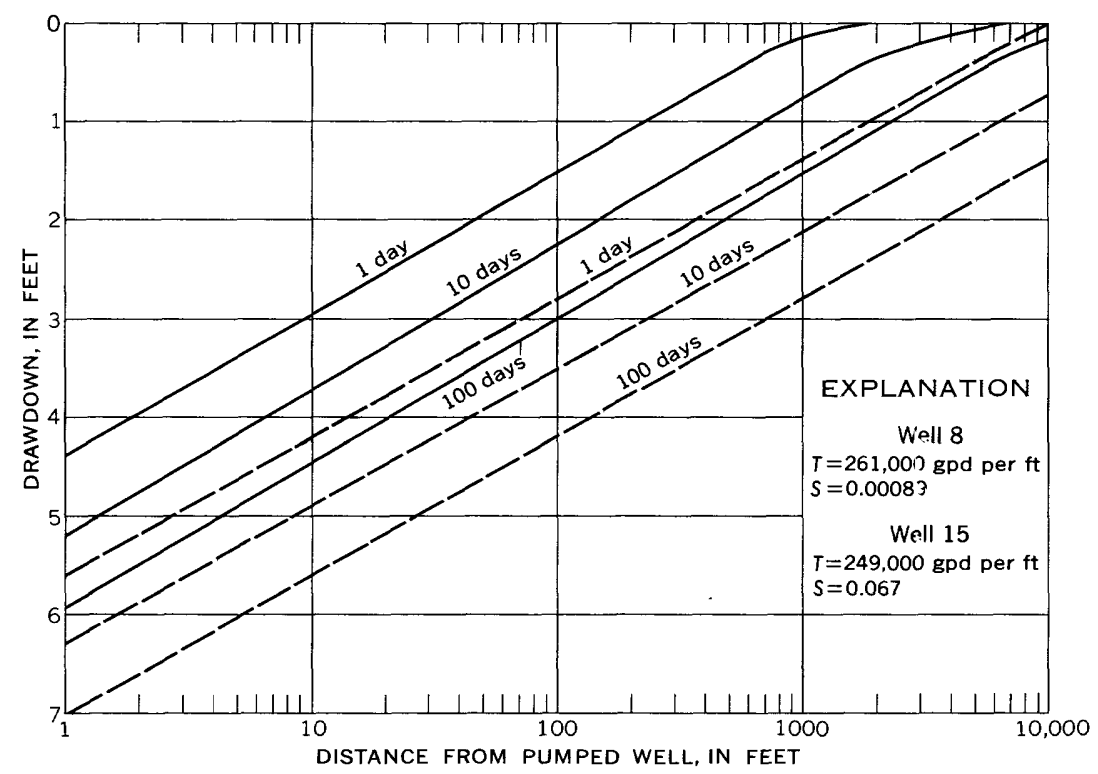

FIgure 14.--Predicted drawdowns near city wells 8 (solid line) and 15 (dashed line), each discharging $700 \mathrm{gpm}$ for selected periods.

ably do not reflect the conditions in Minot during 1964, because the water level near well 15 was about 30 feet higher in 1946 and about 20 feet higher in 1961. This reduction of transmissibility will result in greater drawdowns than the graphs indicate. In addition, interference calculations were made under the assumptions that recharge is zero and that the wells were pumped continuously from storage for periods of 1,10 , and 100 days. The Minot aquifer receives about 3 mgd in natural recharge; thus, the drawdowns indicated on the graphs are greater than those which actually occurred. Also, the drawdown formulas are based on the assumption that the aquifer is infinite in areal extent, is isotropic and homogeneous, and is constant in thickness.

The graphs shown in figures 13 and 14 can be used to determine interference and drawdown as follows. Under the given conditions, well 8 produces a drawdown of 6.3 feet at the well site and about 2.8 feet at a distance of 300 feet from the well after 10 days of pumping $700 \mathrm{gpm}$. Well 8 is about 300 feet from well 7 , and the water level in well 7 would accordingly be lowered about 2.8 feet. Well 7 produces a drawdown of about 7.1 feet at the well site and 3.5 feet at a distance of 300 feet after pumping $700 \mathrm{gpm}$ for 10 days. If wells 7 and 8 are pumped simultaneously, the drawdown in well 7 will be 
about $2.8+7.1=9.9$ feet, and the drawdown in well 8 will be $6.3+3.5=9.8$ feet. If only well 5 is pumped at $700 \mathrm{gpm}$ for 10 days, the drawdown in wells 7 and 8 at the end of this time will be more than 2 feet.

The drawdown (and consequently the well interference) in a watertable aquifer should be less than in an artesian aquifer under similar discharge rates.

The drawdowns resulting from 1,10 , and 100 days of pumping well 15 at $700 \mathrm{gpm}$ are shown in figure 14 . The larger value of $S$, owing to water-table conditions, indicates less drawdown and less interference in this well, which is in the northwestern part of Minot.

Large withdrawals from closely spaced wells in the artesian part of the Minot aquifer should be avoided. Either the discharge rates of these wells should be reduced and more wells should be used, or greater withdrawals should be made from the water-table part of the aquifer.

\section{WATER IN STORAGE}

Hydrographs of the water levels prior to 1960 suggest that much of the water removed before that year was replenished by natural recharge. The rapid lowering of the water level since 1961 and the failure of the water level to recover during periods of minimal pumping would indicate that (1) much of the water is derived from storage, and (2) natural recharge has not equaled the large withdrewals.

If water levels in the Minot aquifer continue to lower at the present rate, the water supply, under present conditions of pumpag? and natural recharge, will become marginal within a few years. The lowering of water levels will be accompanied by (1) increased recharge of poor-quality bedrock water, (2) increased pumpage and well maintenance costs, (3) increased interference between the puraping wells, and (4) possible land subsidence due to compaction of the underlying dewatered materials.

Calculations based on areal extent, thickness, and specific yield of certain rock types within an aquifer provide a rough estimate of available water in storage (Pettyjohn and Randich, 1965b). The area of each rock type, except clay, was measured on the lithofacies maps (pl. 3) by use of a planimeter. The volume of each rock type is the product of the area and the thickness. The available water in storage, in acre-feet, is the product of the saturated rolume and the specific yield.

Approximately 31,000 acre-feet $\left(10.1 \times 10^{9}\right.$ gallons $)$ of water should be available from the 100- to 150 -foot interval, as calculated from the lithofacies map of that interval on plate 3 . Only about 35 feet of that interval, however, is saturated. Consequently, this 35 -foot inter ${ }^{2}$ al of 
the aquifer should yield about 25,000 acre-feet $\left(8.1 \times 10^{\circ}\right.$ gallons $)$ of water. The total water available from depths of 65 to 150 feet is about 56,000 acre-feet $\left(18.2 \times 10^{9}\right.$ gallons $)$.

These figures are considered minimal because the precise areal extent of the Minot aquifer is unknown, and the water in storage in the northwest buried-channel aquifer and the lower Souris aquifer were not used in the calculation. Also, the quantity of water derived by latent drainage from the fine-grained parts of the aquifer was not considered.

Artificial recharge would tend to either stabilize or raise the water level in the Minot aquifer, depending on the rate of infiltration. The following calculations indicate the quantity of water that would be-

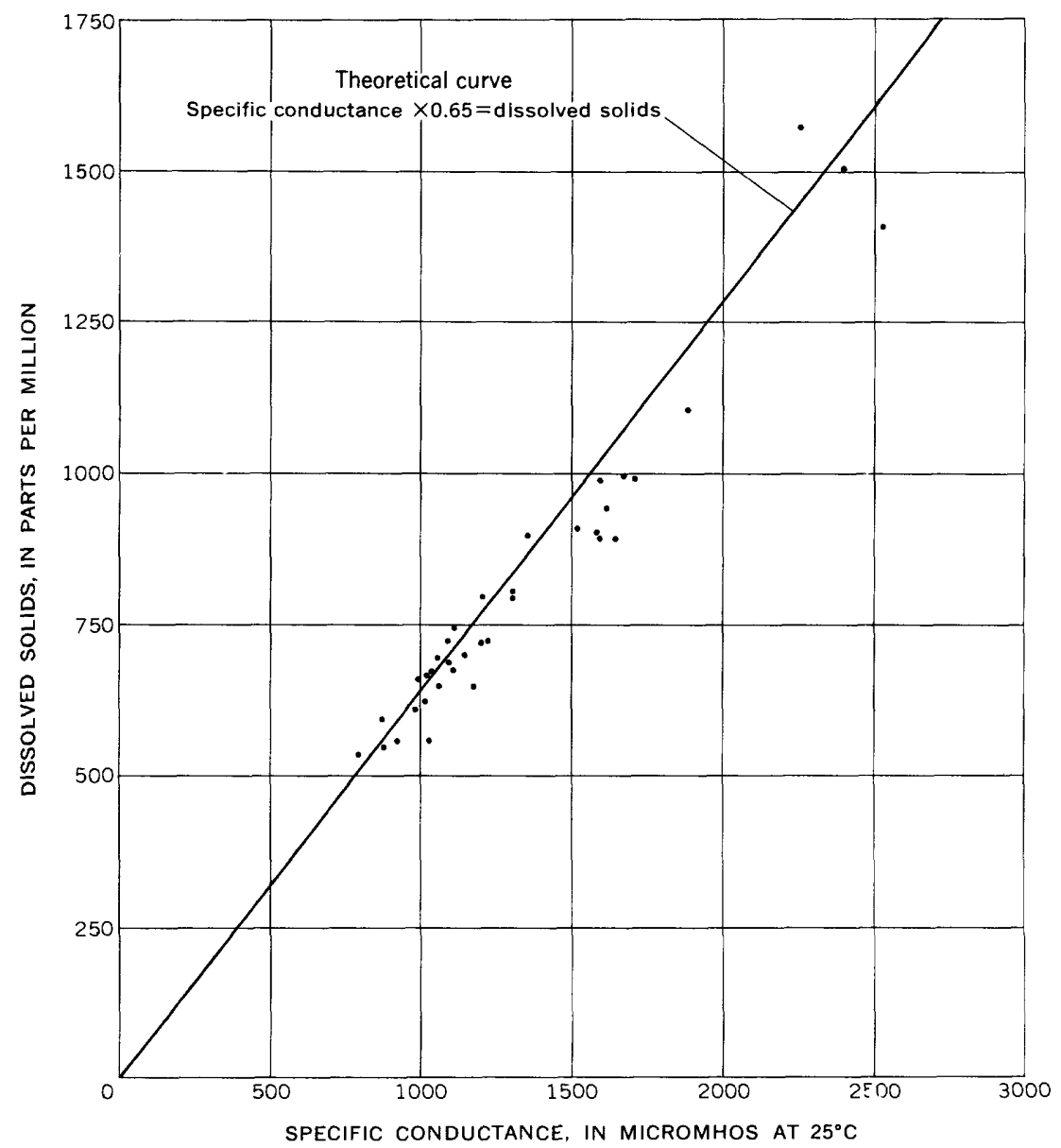

Figure 15.-Relation of dissolved-solids content to specific conductance in ground water in the vicinity of Minot. Data from Pettyjohn and Hills (1965, table 4). 
come available if the water level were raised to within 10 feet of the land surface.

The upper 15 feet of the 50- to 100 -foot interval (pl. 3) is unsaturated, but if this interval were saturated, it would contain at least 11,000 acre-feet $\left(3.6 \times 10^{9}\right.$ gallons $)$ of available water.

If the water level were to be raised to within 10 feet below tro land surface, the interval between 10 and 50 feet would contain at least 17,000 acre-feet $\left(5.5 \times 10^{9}\right.$ gallons $)$ of available water. The combined interval of 55 feet would provide at least 28,000 acre-feet $\left(9.1 \times 10^{9}\right.$ gallons) of available water. However, at least twice as much water would be needed to saturate the interval as would be available to wells.

\section{QUALITY OF WATER}

The chemical quality of ground water differs considerably throughout the Minot aquifer (table 5). The geochemistry of the Minct aquifer is very complex because in places this aquifer consists of several interconmected aquifers that vary in composition and grain size. In addition, mixing of waters of different chemical characteristics, chemical reactions-such as base exchange and absorption of ion--and changes in chemical equilibrium owing to changes in hydrostatic pressure all tend to increase the complexity of the water-quality problems.

The concentration of dissovled solids in ground water in the Minot area ranges from 529 to $1,570 \mathrm{ppm}$ (parts per million) (Pettyjohn and Hills, 1965, table 4). The U.S. Public Health Service (1962) suggested a maximum of $500 \mathrm{ppm}$ of total dissolved solids for usable water; however, this limit is not feasible in most parts of North Dakota.

An approximate measurement of dissolved solids in water can be obtained by determining the specific conductance (fig. 15). Snecific conductance refers to the capacity of the water to conduct an electric current. The ability to conduct a current varies according to the temperature of the water and to the concentration and degree of ionization of the components in the water. Specific conductance indicates the quantity of constituents but does not indicate the relative concentrations of the various components.

Generally, water from the Minot aquifer is hard and of the celciummagnesium bicarbonate type. Among the municipal wells the hardness ranged from $44 \mathrm{ppm}$ to $590 \mathrm{ppm}$. The sulfate content ranged from 26 to $255 \mathrm{ppm}$. The source of sulfate in the Minot aquifer is not definitely known; however, the sulfate is probably derived from gypsum (calcium sulfate) in the glacial drift. The iron content in water from the Minot aquifer is commonly high, ranging from 0.25 to $3.6 \mathrm{ppm}$. Concentrations of iron in excess of $0.3 \mathrm{ppm}$ will cause staining of laundry and utensils. The chloride content in city wells 


\begin{tabular}{|c|c|c|}
\hline & $\mathrm{H}^{\mathrm{d}}$ & 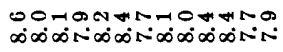 \\
\hline & 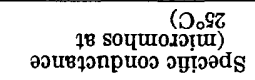 & 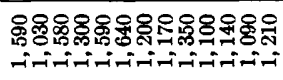 \\
\hline & -uọqdrosp8-umntpos & 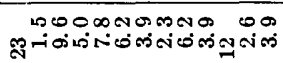 \\
\hline $\bar{x}$ & umịpos quәəxәd & 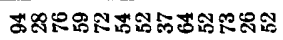 \\
\hline Ä & әңвиоствәио $\mathbf{N}$ & 00000000000 ్ㅣㅇㅣ \\
\hline ثै & $\begin{array}{c}\text { unṇsau } \\
\text {-geur uṇฺ̣: }\end{array}$ & 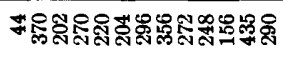 \\
\hline : & 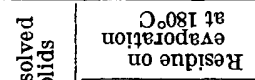 & ธ్రం \\
\hline 产 & $\stackrel{\omega}{A}^{\circ}$ & బద్రి: \\
\hline 总 & (g) uosog & $000000000^{R} .000$ \\
\hline$\frac{\pi}{9}$ & 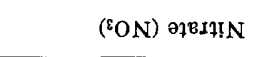 & $\begin{array}{l}000000000 \\
\text { oofitiontitivitinti }\end{array}$ \\
\hline$\stackrel{\Phi}{\Phi}$ & (甘) әр!10 [H & 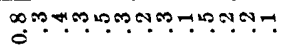 \\
\hline : & 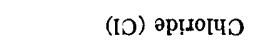 & 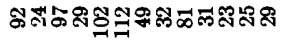 \\
\hline 气็ & ('OS) әұвנ[ns & 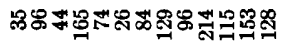 \\
\hline 草 & 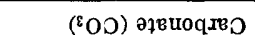 & $\$ 00009000$ \\
\hline$\Xi$ & 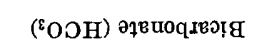 & 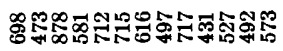 \\
\hline 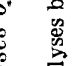 & (X) un!̣sseq0d & 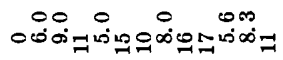 \\
\hline$\frac{\pi}{4}$ & (EN) unțpos & 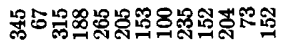 \\
\hline 胥 & 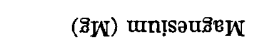 & 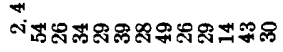 \\
\hline$\Xi$ & 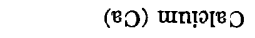 & 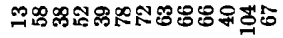 \\
\hline 荌 & (әH) U0II & 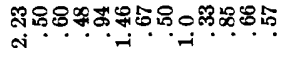 \\
\hline 苋 & (zOIS) вอ!ts & 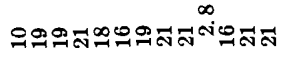 \\
\hline $\bar{\Xi}$ & 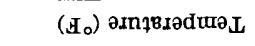 & 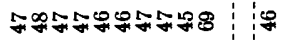 \\
\hline 竎 & 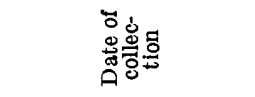 & 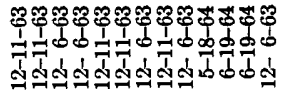 \\
\hline 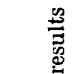 & 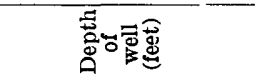 & 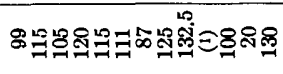 \\
\hline 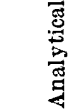 & 要 & 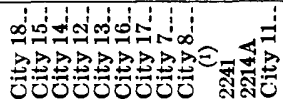 \\
\hline & 总 & 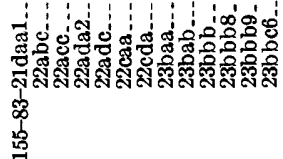 \\
\hline
\end{tabular}


$5,6,9$, and 10 , and in the Minot State College well is relatively high, ranging in concentration from 137 to $338 \mathrm{ppm}$. The U.S. Public Health Service (1962) recommended that the maximum chloride content of public water supplies be not more than $150 \mathrm{ppm}$ for mos'. uses.

Specifically, the chemical quality of the ground water differs to such an extent as to be identifiable (fig. 16) in at least four areas in the Minot aquifer.

In area $A$, water from well 18 has a high sodium-potassium concentration and a high bicarbonate-carbonate concentration (fig. 16, table 5). Also, the water is brown from leaching of the abundant datrital lignite in the aquifer and of the beds of lignite in the Fort Union Formation. The sodium-potassium concentration and the bicarbonate-carbonate concentration in water from well 18 are markedly higher than those in other municipal wells.

In area $B$, municipal wells $13,14,16$, and 17 have larger scdiumpotassium, bicarbonate-carbonate, and chloride concentrations than most of the other municipal wells (table 5). The wells in ares, B are probably recharged predominantly from the south and southwest and from the underlying Fort Union Formation, as suggested by the waterlevel contours shown in plate 3 . The abundance of lignite fragments in this part of the aquifer causes the water to appear slightly hrown.

Area $C$ includes the valley fill composed predominantly of send, in the northwestermmost part of Minot. Municipal wells 7, 8, 11, 12, and 15 are in area $C$. The generally low dissolved-solids content and the other chemical characteristics of the water from these wells, if compared with those of surface-water analyses, suggest that recharge from surface water takes place in this area (table 5). Geologic evidence also suggests the occurrence of surface-water recharge. Water from springs and stream runoff is collected in a number of tributary valleys that empty onto the rather flat flood plain of the Souris River. Also the large gravel pit at the west end of Minot forms a catchment basin that provides recharge to the Minot aquifer.

Area D includes wells 5, 6, 9, and 10, which yield water containing more dissolved solids, chloride, magnesium, and sulphate but less sodium-potassium and bicarbonate-carbonate than the other wells. The concentration of chloride is much higher than in water from the other municipal wells (table 5). Water of high chloride concentration moves southeastward from the northwest buried-channel aquifer and recharges the Minot aquifer near wells 5, 6, 9, and 10, as shown by the water-level contours on plate 3 . The low sodium-potassium content of the water in area $D$ indicates that little or no recharge is received from the Fort Union Formation. 


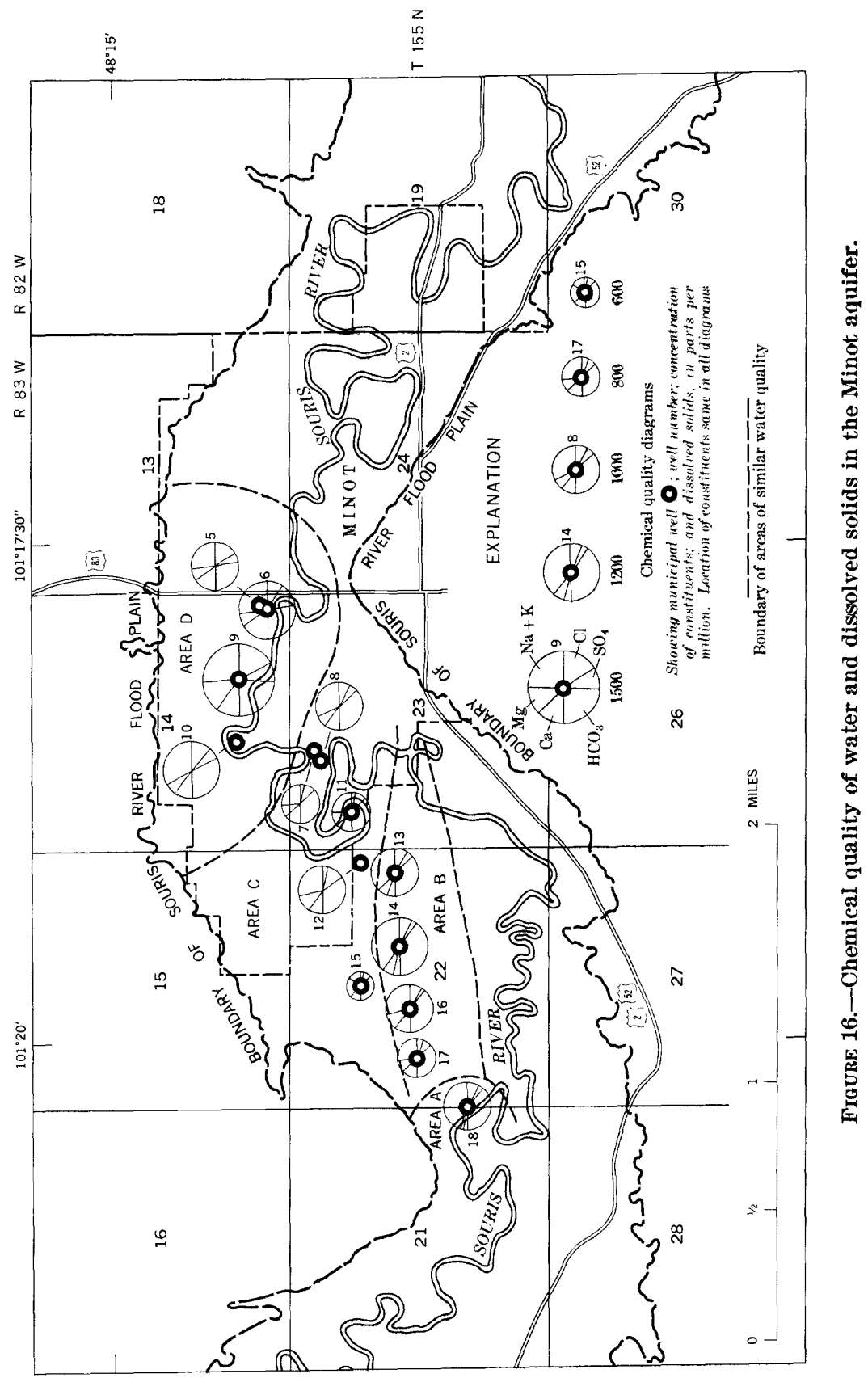


The shallow aquifer in Oak Park consists of sand that is exposed at land surface and is about 20 feet thick. The water level in the aquifer fluctuates according to the stages of the Souris River. A number of private wells and test holes tap this aquifer. The quality of the water in the shallow aquifer is similar to that in the Minot aquifer, but the water generally has a lower sodium-potassium content and a higher nitrate concentration. The lower sodium-potassium content in this water may be attributed to the fact that the shallow aquifer receives most of its recharge from the Souris River and directly from land surface; little or no recharge occurs from the Fort Union Formation. The nitrate concentration varies considerably within shor, distances in the shallow aquifer. Water in the oxbow lake in Oak Park contained $50 \mathrm{ppm}$ nitrate in May 1964. This high concentratior was the result of plant and animal refuse and sewage. At that tim? the nitrate content was $20 \mathrm{ppm}$ in test hole $2225 \mathrm{~A}, 30 \mathrm{ppm}$ in test hole $2226 \mathrm{~A}$, and $1.0 \mathrm{ppm}$ in test hole $2228 \mathrm{~A}$.

Both chemical and geologic evidence indicate that the shallow aquifer is more permeable in the eastern part of Oak Park than in the western part, and the high concentration of nitrate can be attriluted to rapid recharge from the Souris River and the oxbow lake. Consequently, water from wells tapping the shallow aquifer should be analyzed frequently, because nitrate concentrations may at times increase markedly and may approach the maximum limits (45 ppm) established by the U.S. Public Health Service.

\section{SUMMARY AND CONCLUSIONS}

The Mnot aquifer consists of glaciofluvial sand and gravel in the Souris River valley in the vicinity of Minot, N. Dak. The acuifer is highly permeable but of limited areal extent, and the major part is within the Minot city limits. Water in the Minot aquifer crcurs under both artesian (confined) and water-table (unconfined) conditions. The maximum coefficient of transmissibility determined is about 250,000 gpd per $\mathrm{ft}$. The aquifer is recharged predominantly by lateral movement of water from aquifers in adjacent buried chennels and by seepage from the Souris River. Bedrock sources and direct infiltration of precipitation account for a small amount of recharge.

Since 1916 the water level in the Minot aquifer has declined more than 70 feet in places of heavy pumping. The most rapid dacline has occurred since 1961 following completion of eight new municipal wells and subsequent heavy pumping. The city well field consists of 16 wells, of which 13 are utilized. Average daily pumpage ir 1963 was about $3.5 \mathrm{mgd}$. During June-August 1963, pumpage was probably more than $7 \mathrm{mgd}$. Pumpage will need to be increased to supply 
the needs of the rapidly growing city and the Minot Air Force Base, 14 miles north.

Under existing conditions of natural recharge and pumpage, the water supply from the aquifer probably will become marginal within a fairly short time. To counteract the water-level declines, the city could take the following actions :

1. Deepen the existing municipal wells. This, however, would only alleviate the problem temporarily.

2. Test drill and test pump the aquifers to determine how much water is available from the North Hill, South Hill, Sundre buried-channel, lower Souris, and northwest briried-channe] aquifers as outlined in this report.

3. Augment the water supply of the Minot aquifer by means of artificial recharge. Potential artificial recharge sites are in the western part of Minot and in Oak Park. These areas are near the Souris River, which is a potential source of recharge.

The Fort Union Formation of Tertiary age also provides small quantities of water in the Minot area. The water is soft and has a high content of sodium and potassium. Water from the glacial drift is hard and is of the calcium bicarbonate type. A shallow aquifer in the Oak Park area contains as much as $30 \mathrm{ppm}$ nitrates.

\section{SELECTED REFERENCES}

Akin, P.D., 1947, Geology and ground-water conditions at Minot, North Dakota : North Dakota Geol. Survey Ground-Water Studies, no. 6, 99 p.

Andrews, D. A., 1939, Geology and coal resources of the Minot, region, North Dakota : U.S. Geol. Survey Bull. 906-B, p. 43-84.

Bavendick, F. J., 1952, Climate and weather in North Dakota: North Dakota State Water Conservation Comm., $126 \mathrm{p}$.

Bradley, Edward, 1963, Relation of surface and ground water in the Souris River valley near Minot, North Dakota: U.S. Geol. Survey open-file report, $11 \mathrm{p}$.

Krumbein, W. C., and Sloss, L. L., 1956, Stratigraphy and sedimentation: San Francisco, W. H. Freeman \& Co., $497 \mathrm{p}$.

LaRocque, G. A., Jr., Swenson, H. A., and Greenman, D. W., 1963, Tables of hydrologic data, Crosby-Mohall area, North Dakota : U.S. Geol. Survey openfile report, $508 \mathrm{p}$.

Lemke, R. W., 1960, Geology of the Souris River area, North Dakota: U.S. Geol. Survey Prof. Paper 325, 138 p.

North Dakota State Water Conservation Commission, 1957, Surface-water resources of North Dakota : p. 123-124.

Pettyjohn, W. A., and Hills, D. W., 1965, Geohydrology of the Souris River valley in the vicinity of Minot, North Dakota; Ground-water basic data: North Dakota State Water Comm., Ground-Water Studie's, no. 65, 89 p. 
Pettyjohn, W. A., and Randich, P. G., 1965a, Geohydrologic use of lithof reies maps in glaciated areas [abs.] : Am. Geophys. Union Trans., v. 46, p. 521.

1965b, Hydrologic applications of lithofacies clastic-ratio maps [abs.]: Jour. Petroleum Technology, Sept., p. 1069.

Simpson, H. E., 1929, Geology and ground-water resources of North Dalota: U.S. Geol. Survey Water-Supply Paper 598, 312 p.

U.S. Geological Survey, 1961-64, Surface water records of North Dakota and South Dakota: Open-file reports.

U.S. Public Health Service, 1962, Public Health drinking water standards: Pub. $956,61 \mathrm{p}$.

U.S. Weather Bureau, 1960-63, Climatological data. North Dakota, annual sum. maries: r. 69-72. 


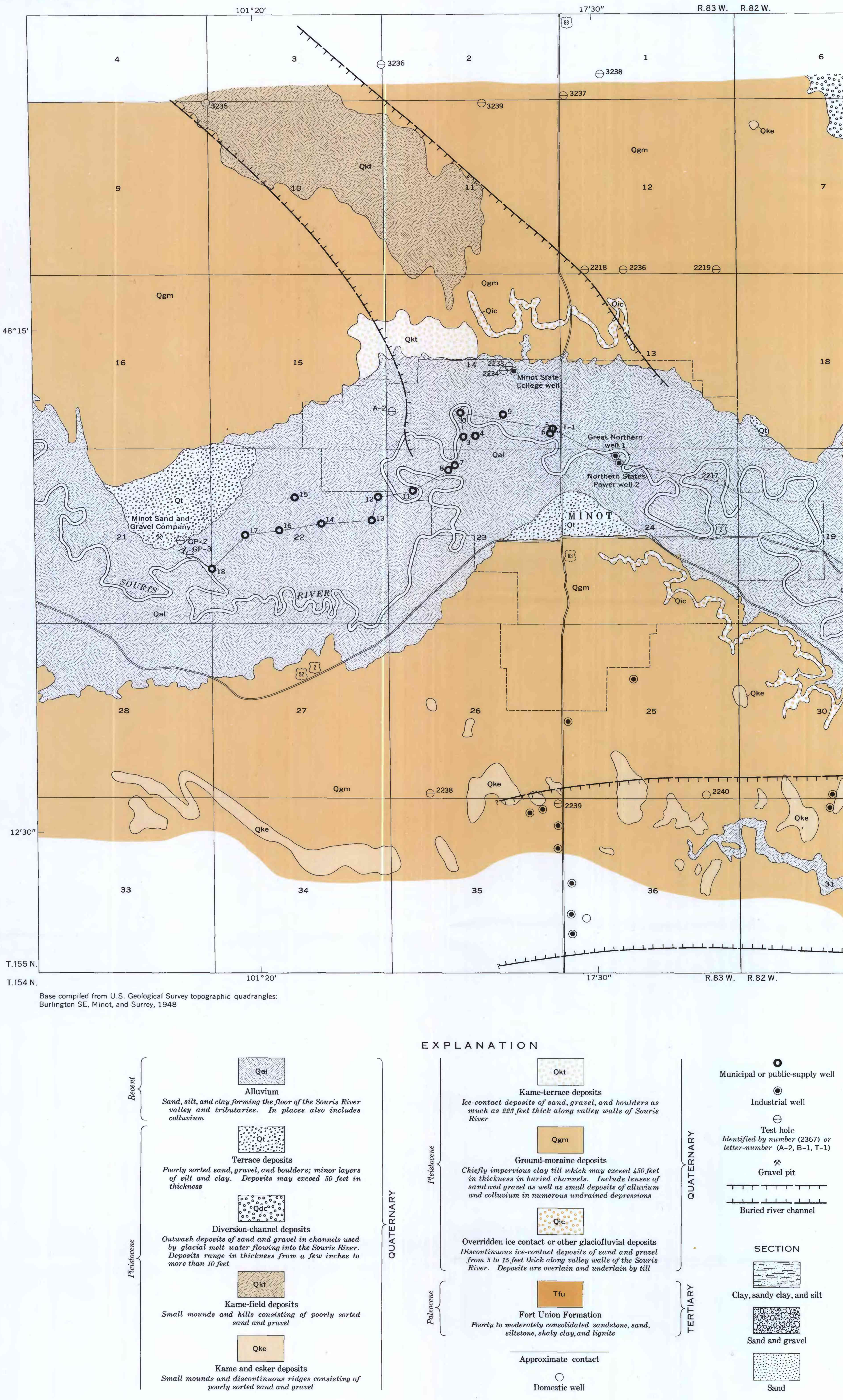

$$
\text { scalk } 122000
$$



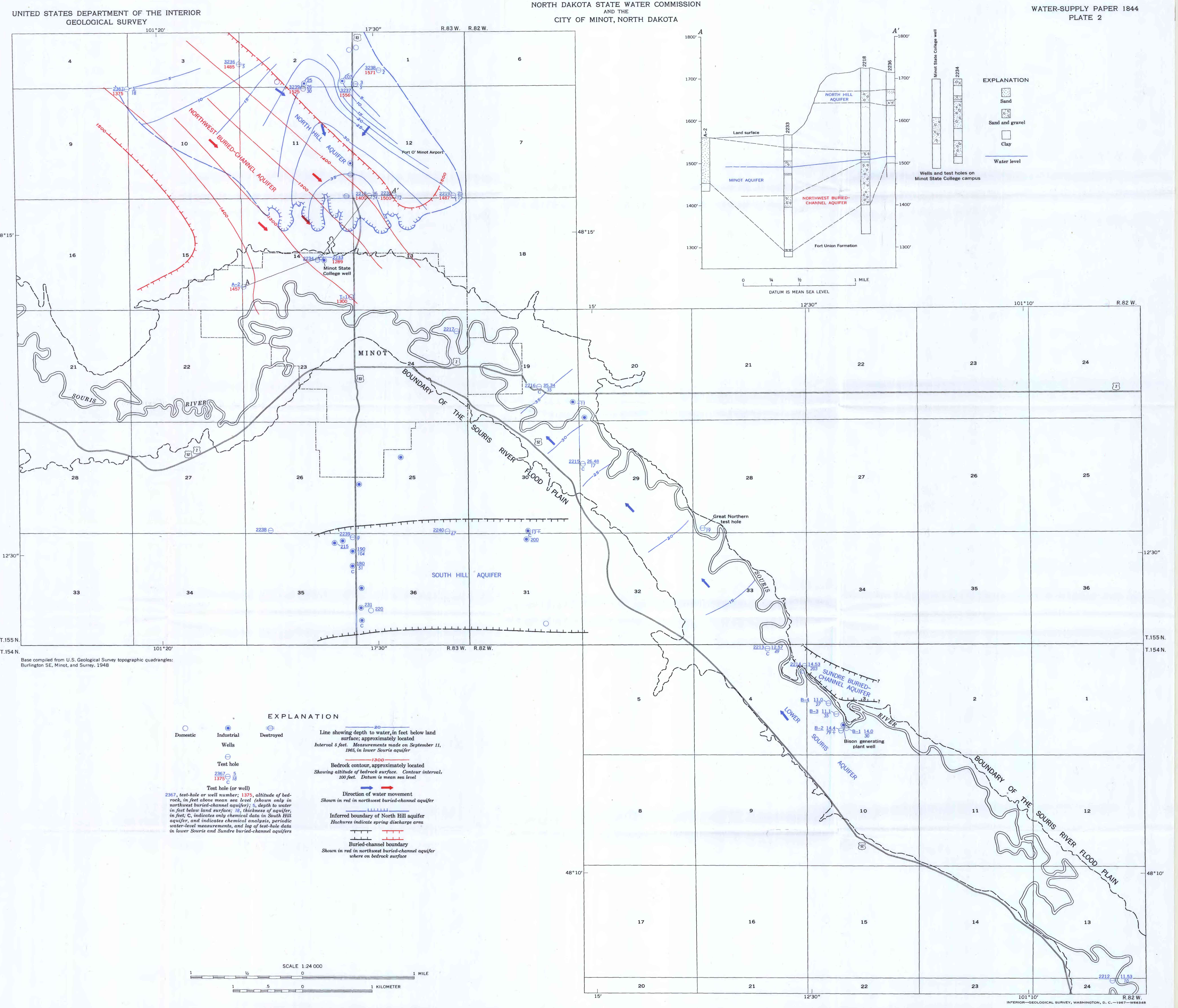

MAP SHOWING LOCATION AND HYDROLOGY OF NORTH HILL, SOUTH HILL, LOWER SOURIS, SUNDRE BURIED-CHANNEL

AND NORTHWEST BURIED-CHANNEL AQUIFERS, SOURIS RIVER VALLEY, MINOT AREA, NORTH DAKOTA 



MAPS SHOWING LITHOFACIES GRAIN-SIZE RATIO, GENERALIZED PIEZOMETRIC SURFACE, AND DECLINE OF WATER LEVEL FOR MINOT AQUIFER 